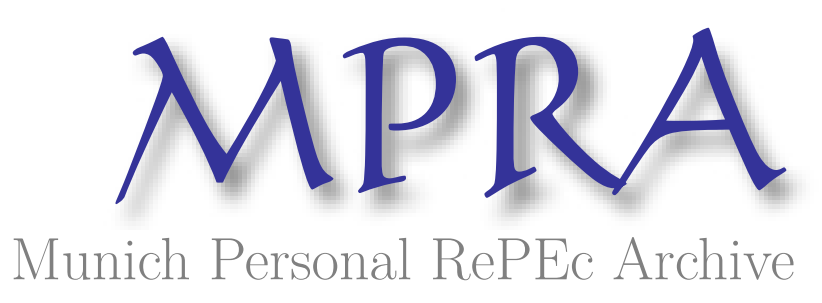

\title{
What happened to profitability? Shocks, challenges and perspectives for euro area banks
}

Cheng, Gong and Mevis, Dirk

European Stability Mechanism

17 August 2015

Online at https://mpra.ub.uni-muenchen.de/66150/

MPRA Paper No. 66150, posted 18 Aug 2015 05:52 UTC 


\title{
What Happened to Profitability? Shocks, Challenges and Perspectives for Euro Area Banks *
}

\author{
Gong Cheng and Dirk Mevis ${ }^{\dagger}$ \\ European Stability Mechanism
}

This version: August 17, 2015

\begin{abstract}
This paper uses a newly constructed dataset including financial statement information of 311 banks in the euro area to analyse the evolution of bank profitability before and after the Global Financial Crisis and the subsequent European crisis. We first document the general trends in the changes in banks' profitability with a particular focus on country and bank heterogeneity. We find that the profitability of banks in different parts of the monetary union was hit by multiple shocks of different nature. Based on this, we then propose an econometric analysis of the drivers behind the evolution of bank profitability by discriminating factors relative to macroeconomic conditions, bank funding and portfolio structures, and new banking regulations in the euro area.
\end{abstract}

JEL Classification: G21, G28, G33, L25

Keywords: bank, profit, return on asset, bank regulation, bank business model

${ }^{*}$ We thank members of the Economics, Strategy and Banking department at the European Stability Mechanism for very fruitful discussions. Special thanks go to Antonello D'Agostino, Aitor Erce and Paolo Fioretti. We also thank the scientific committee of 2015 IFABS conference. The views presented in this paper are those of the authors and do not necessarily reflect those of the European Stability Mechanism/European Financial Stability Facility. All remaining errors are our own.

${ }^{\dagger}$ Address correspondence to: 6a, Circuit de la Foire Internationale, L-1347 Luxembourg. Email: G.Cheng@esm.europa.eu, D.Mevis@esm.europa.eu. 


\section{Introduction}

In the current debate, many observers are concerned that profitability of euro area banks has been low and may continue to trend downward. Bank profitability is, however, essential for the economic recovery, the successful implementation of new bank regulation and the rebuilding of fiscal sustainability in the euro area. In the context of the Global Financial Crisis and the subsequent economic recession in Europe, the banking sector remains the main financing vehicle to boost aggregate demand and to channel deposits and other funding to the real economy. Sufficient bank profitability is thus necessary for financial intermediation to function and to foster economic activity. According to IMF (2014), only $26 \%$ of large euro area banks are capable of supporting the recovery as opposed to $66 \%$ globally. Moreover, the trade-off between reducing risks and maintaining banks' ability to generate sustainable profits accompanies any discussions about more stringent capital and liquidity requirements facing banks. Low profitability hinders the willingness of banks to embrace new regulations ${ }^{1}$. Finally, the sovereign debt crisis in the euro area has demonstrated the force of the malicious link that can develop between sovereign and bank balance sheets due to the implicit support from sovereigns. Higher and sustainable bank profitability would inherently strengthen bank balance sheets and weaken this link, as contingent fiscal liabilities arising from state aid for systemic banks decline. ${ }^{2}$

In this context, our paper aims at documenting the most recent stylised facts on the profitability of euro area banks and identifying the main driving forces of

\footnotetext{
${ }^{1}$ See Hanson et al. (2011), Barth et al. (2013), Ayadi et al. (2015) for discussions on the relationship between bank performance and regulatory requirements.

${ }^{2}$ See Erce (2015) for a discussion on the bank-sovereign feedback loop.
} 
its recent evolution. Our main contribution is twofold. First, we constructed a new bank-level dataset covering 311 banks in 19 euro area member states from 2005 to 2014. We will explore different income and cost streams of European banks jointly with macroeconomic cycles in the euro area. Second, we propose a combined micro and macro approach. The micro approach is based on a "bottom up" bank analyst-type perspective. We look at individual banks' balance sheets, the composition of their profits, and their business models. In addition, our bank analysts perspective provides us with a view on the anatomy of the crisis that euro area banks went through and how different phases impacted on individual income streams.

This data crunching exercise allows us to find some "usual suspects" for our econometric analysis that constitutes our "top down" macroeconomist's perspective. We run regressions using determinants that we identify from the micro approach in conjunction with country and crisis dummies as well as macroeconomic variables. In particular, in the econometric analysis we take account of the insights from the statistical data analysis regarding the timing, the business model and geographical aspects of profitability developments. The objective of this macro approach is then to extract the common factors that drive the trend in euro area banks' profits.

Our study generates two sets of interesting results. First, we show that European banks have been hit by two shocks of different nature. The first shock occurred in 2008-2009 with the spillovers from the crisis in subprime mortgage markets in the United States and the collapse of Lehman Brothers. This shock hit European banks through their securities holdings and wholesale funding and 
thus most affected the banks that had diversified activities and are located in financially more developed countries ${ }^{3}$. The second shock to profitability took place in 2011-2012 with the deepening of the recession and the unwinding of the European debt crisis. As opposed to the first, the second shock mainly increased banks' credit impairment expenses due to the increased default probability in the private sector and weakened confidence around sovereign debt sustainability. As a result, banks that are more affected by the second shock are those specialised in traditional lending activities and often located in financially less developed euro area countries ${ }^{4}$. Some of these countries experienced real estate busts which exacerbate the weakness now. The first shock also seems to have a "one-off" effect on banks' profits while the effects of the second shock have been more pronounced and long-lasting.

Second, using the most recent data, we confirm and complement findings in the literature on the role of macroeconomic variables and that of banks' balance sheet structure on profitability. A higher equity share relative to total assets is unambiguously correlated with higher profits. This result remains valid when using both total equity or regulatory capital (Core Tier 1 and Tier 1 capital) and when subjected to a number of alternative specifications. Banks' net income is positively associated with macroeconomic cycles measured by GDP growth via lower impairment costs. A higher government debt ratio relative to a country's GDP generally lowers the banking sector's profits via lower net non-interest income and

\footnotetext{
${ }^{3}$ In the following discussions, we refer to financially more developed euro area countries as core Europe. This group includes Austria, Belgium, Germany, France, Finland, Luxembourg and Netherlands.

${ }^{4}$ This group of countries, including Cyprus, Greece, Portugal, Ireland, Italy and Spain, is called hereafter south Europe. Countries falling in this category include Italy and countries that have requested a financial assistance programme with European Financial Stability Facility (EFSF) or European Stability Mechanism (ESM).
} 
higher impairment expenses. We also find that bank business models, measured by the relative size of loan portfolio over securities portfolio and the density ratio of risk-weighted assets over total assets, matter. The marginal effect of the funding structure is however not significant. More importantly, one original result from our study shows that the marginal effect of GDP growth and government debt ratio is more pronounced in banks with a higher risk-weighted asset ratio, namely banks specialising in traditional funding/lending activities.

The literature on bank profitability and its determinants can be dated back to the 1980s and 1990s following the wave of financial deregulation. Demirguc-Kunt and Huizinga (2000), use bank-level data to uncover the determinants of commercial banks' interest margins and profitability. They show that differences in interest margins and bank profitability stem from bank characteristics, macroeconomic conditions, explicit and implicit bank taxation, deposit insurance regulation, overall financial structure, and several underlying legal and institutional characteristics. Following Demirguc-Kunt and Huizinga (2000), a number of economists have proposed country-specific studies on the profitability of national banking sectors. Jian et al. (2003) investigate the Hong Kong banking sector's profitability in the aftermath of the Asian financial crisis. These authors find that macroeconomic environment as well as bank specific factors, such as operational efficiency and business diversification, are key determinants of bank profitability. Athanasoglou et al. (2008) use a GMM technique to study the profitability of Greek banks from 1985 to 2001. They demonstrate that the market structure and bank-specific determinants affect bank profitability significantly. With respect to this strand of literature, our paper provides very recent stylised facts with a focus on the 
impact of crisis shocks on profitability of major euro area banks. We focus on euro area banks instead of conducting a large cross-country comparison because euro area banks, notwithstanding heterogeneity, face similar institutional cultures and regulatory requirements. This renders the sample more homogeneous for the econometric analysis .

The European Central Bank provides financial stability reviews on a regular basis. Its latest review - ECB (2015) - includes a panel study of the determinants of bank profitability in 19 European countries, including a few non-euro area member states. Although their approach is similar to ours, we put an emphasis on countryspecific and sub-regional heterogeneities in the euro area and uncover the impact of profitability determinants on different streams of banks' income. Moreover, our study sheds light on the interaction between macroeconomic variables and bankspecific features and documents the impact of different shocks that banks have endured since the onset of the Global Financial Crisis.

In our data crunching exercise and econometric analysis, we are also guided by the recent literature regarding the choice of determinants of bank profitability. Our study is especially inspired by Albertazzi and Gambacorta (2009) and Bolt et al. (2012). The former evaluate the effects on banking profitability of shocks to macroeconomic and financial factors. Their study focuses on the differences between European banks and Anglo-Saxon banks, in particular regarding the impact of adopting the single currency in Europe. Using similar estimation methods (of a set of equations for net interest income, non-interest income, and provisions), our paper focuses on the impact of the Global Financial Crisis and the subsequent financial instability in Europe on bank profitability. Bolt et al. (2012) provide a detailed account on the impact of economic activities on bank profitability, espe- 
cially during recessions. However, the dataset used in that paper ends in 2007 and does not cover the most recent phase of financial instability in Europe. Compared with Albertazzi and Gambacorta (2009) and Bolt et al. (2012), our paper also puts a stronger emphasis on bank balance sheet items and their interaction with macroeconomic conditions.

Alessandri and Nelson (2015) examine the impact of funding costs on bank profitability. They pay particular attention to the relationship between interest rates and bank profitability using both a theoretical model and empirical investigation of British banks. Our paper controls for money market conditions and confirms Alessandri and Nelson (2015)'s finding that in the short run increases in market rates compress the interest margin. This is not the main focus of the paper. We pay more attention to the asset allocation and finding structure.

Moreover, some papers see bank business models as the main driver of the heterogeneity in profitability. Roengpitya et al. (2014) use a statistical clustering method to identify predominant business models across 220 global banks before and after the financial crisis. Overall they find that retail oriented banks are the most profitable throughout. While confirming the result that the business cycle, crisis shocks and bank business models matter on their own, our paper demonstrates that the choice of business model can accentuate the impact of external shocks and macroeconomic cycles. In addition, the impact of the business model also varies according to different income streams and different macroeconomic conditions.

Finally, there is an increasing interest in the literature regarding impaired loans and loan loss provisioning (e.g. Bikker and Hu 2002, Laeven and Majnoni 2003, Bouvatier and Lepetit 2008). Following this strand of papers, we uncover the 
importance of impaired loans in driving down banks' profitability. This is a particularly salient feature for banks in peripheral Europe. The increased impairment costs that are directly related to the sluggish economic growth perspective in peripheral Europe have a much more pronounced and longer impact on banks' profits in the euro area than the collapse of Lehman Brothers in 2008.

Our paper is organised in the following way. The data and key concepts are explained in Section 2. Section 3 documents the stylised facts on euro area banks' profitability from a bank analyst's viewpoint. Section 4 presents the methodology and the results of our econometric analysis. Section 5 concludes.

\section{Data}

For the analysis in this paper, we constructed a panel dataset covering 10 years of annual financial statement data of 311 banks from 2005 to 2014. The dataset, downloaded from the commercial data provider SnlFinancial, includes balance sheet and income statement data from selected banks in the 19 euro area countries.

We selected banks in the sample according to their size. All euro area banks with a balance sheet larger than $€ 20$ billion are included. ${ }^{5}$ The dataset does not intend to be exhaustive, but aims at selecting a good number of banks across 19 euro area members, including both banks supervised by the Single Supervisory

\footnotetext{
${ }^{5}$ Choosing banks according to a specific size threshold exposes the empirical part of the paper to a potential non-randomisation bias. This means that the estimates could be biased as the fact that banks reach a certain size threshold could be not independent from bank profitability. The fact that the sample is very heterogeneous, however, mitigates this concern. In addition, size is but one of the distinguishing bank specific characteristics.
} 
Mechanism (SSM) and those still under national supervision. The threshold of $€ 20$ billion also allows us to have a quasi equal size of these two groups of banks. ${ }^{6}$

Table 1: Number of banks in the sample, average balance sheet size (in €billion), share of customer loans, bank loans and securities on balance sheet (in percentage points).

\begin{tabular}{lcc|ccc}
\hline & & & \multicolumn{4}{|c}{ Asset distribution } \\
Ctry & banks & Av. Ass. (€bn.) & C. loans (\%) & B. loans (\%) & Sec. (\%) \\
\hline Austria & 13 & 81.11 & 51.97 & 15.35 & 20.52 \\
Belgium & 14 & 201.98 & 51.64 & 12.12 & 30.86 \\
Cyprus & 5 & 21.27 & 68.14 & 12.35 & 16.37 \\
Germany & 61 & 154.69 & 48.38 & 15.25 & 28.42 \\
Estonia & 30 & 8.20 & 81.93 & 7.89 & 3.76 \\
Spain & 47 & 128.82 & 67.18 & 8.18 & 18.43 \\
Finland & 6 & 84.32 & 53.71 & 14.10 & 22.73 \\
France & 56 & 286.74 & 48.73 & 15.48 & 25.46 \\
Greece & 5 & 66.53 & 70.30 & 4.92 & 17.17 \\
Ireland & 13 & 97.97 & 55.70 & 17.82 & 26.83 \\
Italy & 30 & 114.85 & 66.13 & 12.92 & 16.00 \\
Lithuania & 3 & 5.41 & 77.07 & 5.63 & 8.60 \\
Luxembourg & 13 & 70.92 & 41.17 & 21.45 & 26.76 \\
Latvia & 3 & 4.46 & 70.53 & 8.86 & 9.75 \\
Malta & 2 & 6.21 & 55.37 & 10.61 & 27.29 \\
Netherlands & 21 & 333.52 & 58.41 & 8.50 & 22.79 \\
Portugal & 8 & 61.47 & 70.61 & 5.56 & 18.19 \\
Slovenia & 3 & 8.95 & 59.16 & 4.72 & 21.10 \\
Slovakia & 3 & 10.76 & 63.07 & 6.41 & 26.61 \\
\hline All & 311 & 159.11 & 57.17 & 12.69 & 23.02 \\
\hline
\end{tabular}

Source: SnLFinancial, own calculations. Averages are taken across the sample period. Please note that the percentage points do not add up to 100 as there are some (errors and omissions and other minor) asset positions missing in this presentation, and, because the values represent unweighted averages.

\footnotetext{
${ }^{6}$ It is possible that banks in the sample have less than $€ 20$ billion in total assets and are still considered systemic by the SSM. This is mostly the case in smaller euro area countries. In order to fall under the direct supervision of the SSM a financial institution needs to fulfil either of the following criteria: the total value of its assets exceeds $€ 30$ billion, the institution has economic importance for the specific country or the EU economy as a whole (meaning it holds at least $20 \%$ of domestic sector assests and holds more than $€ 5$ billion in total assets), the top 3 institutions (in terms of asset size) in each country, or the total value of its assets exceeds $€ 5$ billion and it has significant cross-border activities. The list of banks under the supervision of the SSM is available here: https://www.bankingsupervision.europa.eu/.
} 
Table 1 provides a summary of the number of banks per country, as well as country averages of the total assets and asset allocation of banks included in our dataset. Our panel dataset is unbalanced as not all banks have been reporting over the complete period starting in 2005.

Banks in the sample are quite diverse. For example, the largest individual banks are located in France. Nevertheless, the Netherlands shows up as having the largest banks on average, as Dutch banks frequently include important insurance business. Another particular case is Italy. Despite the size of the country, the number of observations from Italy is comparably low. This is due to the fact that the Italian banking sector is very fragmented with many small players. Consolidation is quite slow and has only started more seriously over the past decade.

Regarding the structure of banks' portfolios, Table 1 shows that in a few countries the share of customer (retail) loans is below or close to $50 \%$ of the balance sheet. This is the case in Luxembourg, Germany, France, Belgium and Austria. Banks in these countries are generally larger and more oriented towards capital market business. In other countries, customer loans make up between $2 / 3$ and $3 / 4$ of the portfolios. These more traditional banking sectors are mostly located in Greece, Portugal, Italy, Spain and Cyprus.

Table 2 shows the main asset and liability categories we will focus on in the following sections. It also takes two snapshots of average balance sheets of banks in 2007 and 2012. While the regional average hides some underlying discrepancies across countries that we will see in Section 3, one can observe some basic movements. On the asset side, customer loans declined slightly which is a reflection of the deleveraging in the retail credit portfolio. Also, bank loans declined in tandem with the turmoil in interbank markets. Securities holdings gained across the two 
Table 2: Average balance sheet of sample banks pre-and post-crisis.

\begin{tabular}{lc|lc}
\multicolumn{1}{c}{ Assets } & 2007 & \multicolumn{2}{c}{ Liabilities } \\
\hline \hline Customer loans & $57.9 \%$ & Customer de- & $40.3 \%$ \\
& & posits & \\
Bank loans & $14.1 \%$ & Bank deposits & $20.4 \%$ \\
impaired loans & $1.5 \%$ & Central bank & $1.6 \%$ \\
Securities & $21.9 \%$ & Debt & $24.8 \%$ \\
& & Derivatives & $3.1 \%$ \\
\multicolumn{1}{c}{ Assets } & \multicolumn{2}{c}{2012} & Equity Liabilities \\
\hline Customer loans & $55.6 \%$ & Customer de- & $40.0 \%$ \\
Bank loans & $11.9 \%$ & posits & \\
impaired loans & $5.0 \%$ & Central bank & $7.9 \%$ \\
Securities & $23.9 \%$ & Debt & $22.6 \%$ \\
& & Derivatives & $6.1 \%$ \\
& & Equity & $5.7 \%$
\end{tabular}

Please note that these are unweighted averages of selected positions and do not necessarily sum up to 100 . 
periods. This development should be seen amid increased sovereign issuance and banks' need for collateral in times of liquidity shortages. An obvious change is the stark increase in impaired loans. On the liabilities side, all traditional categories of funding declined. Derivatives funding and (not surprisingly) central bank funding increased while equity also slightly rose. Equity had not noticeably increased on average in 2012 but did so in the subsequent years.

Beyond the relative shifts, banks in the euro area have adjusted their balance sheet since the onset of the crisis. In particular, non-core businesses have been sold off and loan portfolios have been reduced. According to ECB (2014) total assets stood at $€ 26.8$ trillion at end-2013 - a decline of $9.4 \%$ as compared to 2012 .

In our study the main measure for profitability is net income scaled by total assets. This can also be assimilated to Return on Assets (RoA). Net income is scaled by total assets so as to facilitate cross-bank and cross-country comparisons. Moreover, RoA is commonly used in the literature to measure the intrinsic capacity of a bank to generate profits. In some studies, capital employed - total assets net of fixed assets - is used as a scaling factor instead. In the commercial world, an alternative and even more important measure of profitability is Return on Equity (RoE hereafter). This measure is popular as it can be set against the abstract cost-of-equity measure which represents the trade-off for the potential investor. Nevertheless, the RoE measure can be strongly influenced by the leverage of the institution. This is why in our study we have chosen net income over total assets as the primary measure of profitability. In addition, we will also pay attention to the components of net income and analyse their evolution over time and the underlying driving force. For this, we split up banks' Net Income $(N I)$ in the following 
ways. According to Equation (1), Net Income is the sum of Net Interest Income $(N I I)$ and Net Non-Interest Income (NonII) including Net Fee and Commission Income $(N F C I)$, Net Trading Income $(N T I)$ and Other Net Income $(O N I)$, minus Operating Expenses $(O E)$ and Impairment Expenses $(I M P)$. When we need to isolate impairment expenses, we can use the decomposition showed in Equation (2), distinguishing Pre-impairment Income (PreImp) from impairment costs. Finally, bank analysts often separate recurring income from non-recurring income, arguing that recurring income, such as net interest income, commissions and fees, tend to be more stable while non-recurring income (defined as Net Trading Income) is subjected to valuation changes and more sensitive to market volatilities. Trading income can also be considered one-off as there is no guarantee that gains will occur in subsequent years. This motivates the decomposition in Equation (3).

$$
\begin{aligned}
N I & =N I I+(N F C I+N T I+O N I)-O E-I M P \\
& =(N I I+N o n I I-O E)-I M P \\
N I & =(N I I+N F C I+N T I+O N I-O E)-I M P \\
& =\text { PreIMP-IMP } \\
N I & =(N I I+N F C I)+(N T I+O N I)-O E-I M P \\
& =R E C+N o n R E C-O E-I M P
\end{aligned}
$$

Our bank-level dataset is complemented by country-level macroeconomic variables as well as common factors capturing funding costs on interbank markets and global financial market volatilities. Macroeconomic variables to control for a 
country's overall economic performance and fiscal policy are extracted from the database World Development Indicators of the World Bank and from the IMF World Economic Outlook database. Variables related to the common monetary policy in the euro area are retrieved from the European Central Bank (ECB). Furthermore, variables related to banking sector aggregates are extracted from Financial Soundness Indicators database of the IMF.

\section{Stylised facts}

The impact of the crisis on bank profitability was channelled directly through profit and loss accounts and indirectly through changes to the operating environment. Banks responded to external shocks by adjusting their balance sheet structure. Changes to risk management framework were required as asset quality started to deteriorate. Stress tests and solvency concerns related to losses led to balance sheet shrinkage and reallocation of capital. For some banks which received state aid, formal restructuring plans were drawn up. Lastly, upcoming regulatory changes - mostly on capital and liquidity requirements - were partially anticipated by banks.

Based on our dataset, we provide below some key stylised facts on banks' profitability dissecting income and expense streams. Thereby, we first present some regional trends. We then address cross-country heterogeneity and show how crisis shocks hit banks in core and in peripheral Europe in very different ways. We also examine how profitability differs in banks according to banks characteristics including different funding structures and asset allocation. Finally, we provide some insight on the impact of newly conceived banking regulations in Europe and 


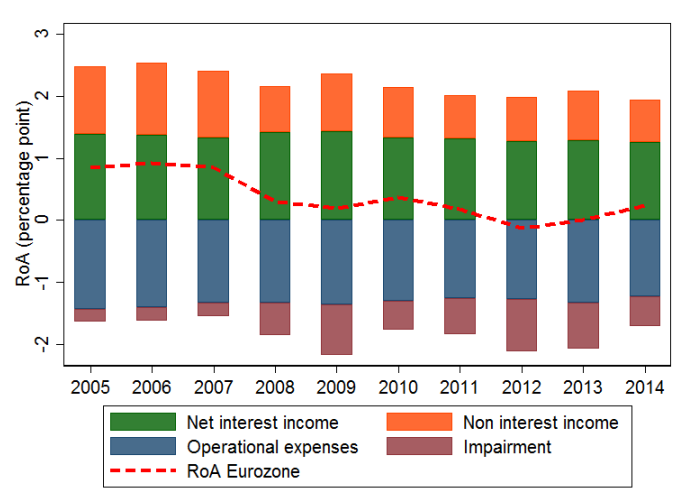

(a) Average returns decomposed.

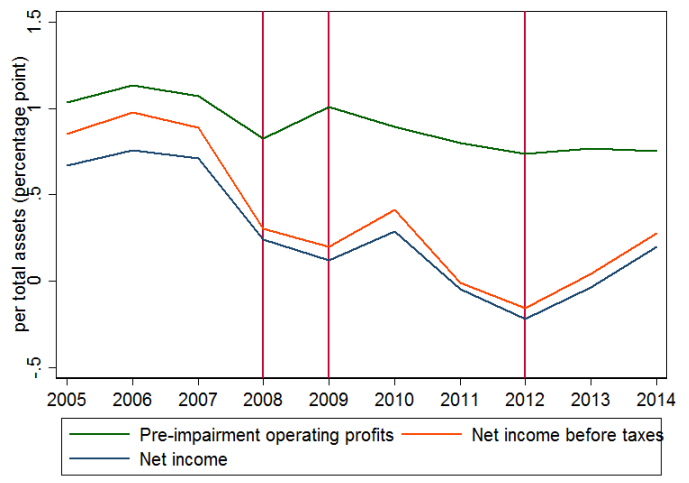

(b) Pre vs. post-impairment

Figure 1: Profitability decomposition in the euro area. Source: SnL Financial, own calculations.

how banks react to them.

\subsection{Multiple crises hit euro area bank profitability}

At the euro area level, we observe a general downward trend in bank profitability from 2005 to 2012, with a slight amelioration from 2013 onwards (see Figure 1a). However, net profits over total assets have not reached pre-crisis levels yet (i.e. above $0.5 \%$ ). One can observe a double dip for euro area banks on average with a first trough occurring in 2009 and a second one in 2012. Finally, Figure 1a also shows that crisis shocks affected different income and expense streams in different ways. Impairment expenses - which peaked in 2009 and 2012 - have played an increasing role in driving down banks' profits.

Figure $1 \mathrm{~b}$ gives an insight into the chronological developments of profitability at the euro area level on average. From 2007 to 2008 a first shock hit euro area banks. Notably one can see that both pre-impairment profits and net income plummeted at this stage. Impairments to financial assets (both securities and loans) 
worsened in 2009 as the gap between pre-impairment profits and net income was widening. However, pre-impairment income was hit as well - most importantly trading income. This income stream somewhat recovers subsequently but after 2009 pre-impairment income suffers from declines in net-interest income. Impairments continue to weigh on profits and hit in two waves with two distinguishable low points in 2009 and 2012.

Figure 2 separates recurring from non-recurring profits. Recurring profits are defined as net interest income and net fee and commission income whereas nonrecurring income typically arises from trading activity. Recurring profits decreased slowly over the observation period whereas non-recurring profits were very volatile. Non-recurring income was particularly hit in the early stages of the crisis in 2008 where it turned negative. This may have been related to the fact that in the early stages of the crisis confidence waned in all markets as volatility was particularly high. For example, the Vix index which is usually taken as an indicator of market risk almost doubled between 2007 and 2008 and peaked in 2009. ${ }^{7}$ Banks that were engaged more strongly in capital markets suffered losses during this period. More traditional, retail oriented banks did not suffer as much from this initial shock. Their profitability suffered later on as retail business started to decline. In Figure 2, one can observe that recurring profits decline slowly throughout the sample period.

The changing nature of the crisis in euro area banks can also be seen in Figure 3. It shows the standard deviations of different components of the income stream of

\footnotetext{
${ }^{7}$ The Vix index is a Chicago Board options exchange market volatility index which measures implied volatility of S\&P 500 index options in percentage points. It climbed from an annual average of 17.7 in 2007 to an 31.6 in 2008 and 31.8 in 2009. In subsequent years it remained elevated but did not return to those peak values. The V2X which is a similar European index based on the Eurostoxx basket mirrored those movements.
} 


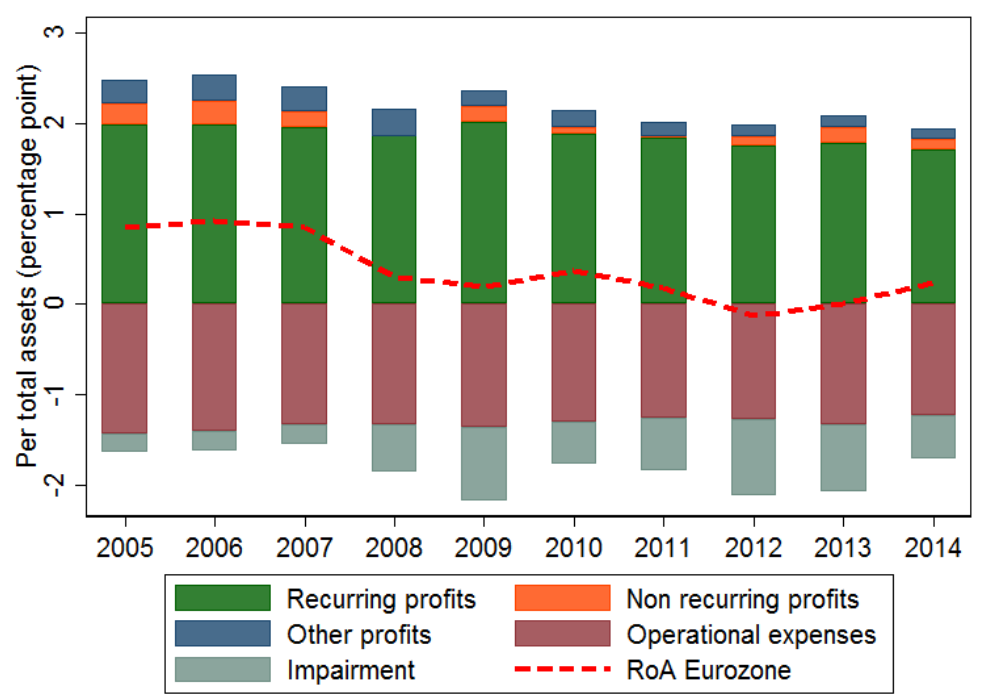

Figure 2: Recurring versus non-recurring profits of banks in the euro area 20052014. Source: SnL Financial, own calculations.

banks across the sample for selected years. The year 2005 (green dashed line) serves as a pre-crisis benchmark. Moving along the years one can see how first heterogeneity increases in net trading income in 2008 followed by impairments. This mostly concerned banks active in securities trading. At a later stage in 2013 a broader range of income components were hit by volatility as the crisis spread more generally. One can see that impairments, operating expenses and non-interest income exhibit high volatility across the sample. Net trading income has meanwhile returned to pre-crisis levels as banks that were hit by the initial shock recovered. Net fee and commission income remained fairly stable throughout the sample.

The different stages of the crisis can be attributed to different time periods but can also be located geographically. We will now focus on the cross-sectional aspects of the crisis. 


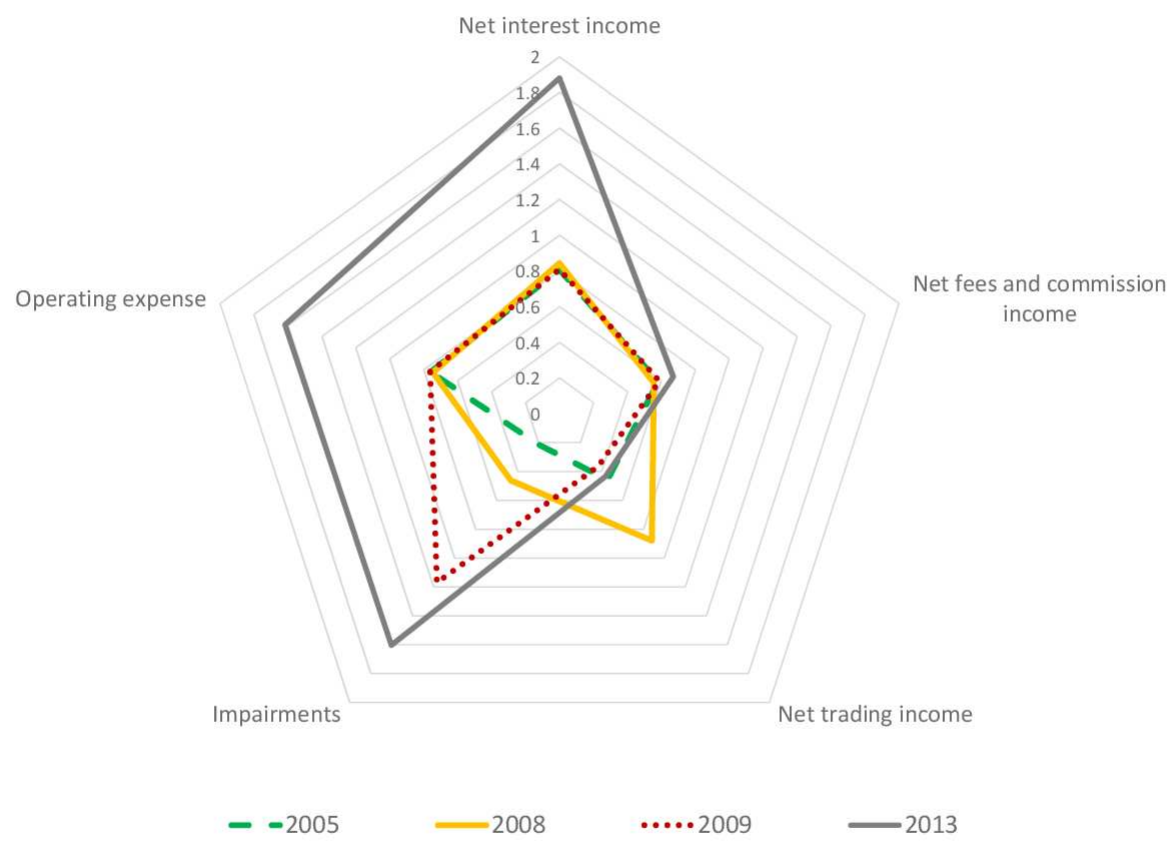

Figure 3: Volatility of main income streams of major banks in the euro area. 2005-2014, selected years. Source: SnL Financial, own calculations. 
Table 3: Evolution of RoA in euro area banks

\begin{tabular}{lllllll}
\hline & \multicolumn{2}{c}{$2005-7$} & \multicolumn{2}{c}{$2008-9$} & \multicolumn{2}{c}{$2010-14$} \\
\cline { 2 - 7 } Country & mean & s.d. & mean & s.d. & mean & s.d. \\
\hline Austria & $0.83 \%$ & $0.76 \%$ & $-0.01 \%$ & $1.14 \%$ & $0.15 \%$ & $1.18 \%$ \\
Belgium & $0.71 \%$ & $0.37 \%$ & $-0.13 \%$ & $0.66 \%$ & $0.38 \%$ & $0.56 \%$ \\
Cyprus & $1.50 \%$ & $0.70 \%$ & $0.84 \%$ & $0.44 \%$ & $-0.68 \%$ & $3.25 \%$ \\
Germany & $0.39 \%$ & $0.46 \%$ & $-0.09 \%$ & $0.83 \%$ & $0.29 \%$ & $0.66 \%$ \\
Estonia & $2.01 \%$ & & $1.77 \%$ & & $1.61 \%$ & $0.77 \%$ \\
Spain & $0.96 \%$ & $0.38 \%$ & $0.37 \%$ & $0.84 \%$ & $-0.58 \%$ & $2.38 \%$ \\
Finland & $1.09 \%$ & $0.24 \%$ & $0.54 \%$ & $0.21 \%$ & $0.64 \%$ & $0.22 \%$ \\
France & $0.76 \%$ & $0.42 \%$ & $0.38 \%$ & $0.49 \%$ & $0.45 \%$ & $0.51 \%$ \\
Greece & $1.54 \%$ & $0.27 \%$ & $0.60 \%$ & $0.88 \%$ & $-1.27 \%$ & $1.14 \%$ \\
Ireland & $1.45 \%$ & $1.63 \%$ & $0.55 \%$ & $1.85 \%$ & $-0.91 \%$ & $2.67 \%$ \\
Italy & $1.24 \%$ & $0.5 \%$ & $0.61 \%$ & $0.52 \%$ & $0.01 \%$ & $1.25 \%$ \\
Lithuania & $1.19 \%$ & $0.56 \%$ & $-1.86 \%$ & $3.73 \%$ & $1.36 \%$ & $1.12 \%$ \\
Luxembourg & $0.90 \%$ & $0.28 \%$ & $0.37 \%$ & $0.77 \%$ & $0.26 \%$ & $1.49 \%$ \\
Latvia & $1.96 \%$ & $0.23 \%$ & $-2.65 \%$ & $4.51 \%$ & $1.05 \%$ & $1.40 \%$ \\
Malta & $2.07 \%$ & $0.39 \%$ & $1.29 \%$ & $0.48 \%$ & $1.42 \%$ & $0.29 \%$ \\
Netherlands & $0.55 \%$ & $0.42 \%$ & $-0.17 \%$ & $0.68 \%$ & $0.32 \%$ & $1.31 \%$ \\
Portugal & $0.99 \%$ & $0.31 \%$ & $0.56 \%$ & $0.43 \%$ & $-0.03 \%$ & $0.66 \%$ \\
Slovenia & $1.36 \%$ & $0.39 \%$ & $0.12 \%$ & $0.37 \%$ & $-2.16 \%$ & $4.36 \%$ \\
Slovakia &. &. & $1.37 \%$ & $0.50 \%$ & 1.71 & 0.27 \\
\hline
\end{tabular}

\subsection{Cross-country perspective}

Table 3 gives an overview of the average country values for pre-tax return on assets (RoA) in three periods: 2005-7, 2008-9 and 2010-14. Decreasing profitability can be observed for most euro area countries from 2005 to 2014. The table focuses on the three time periods that were identified above as being essential in the development of the crisis. The first two columns give the pre-crisis average and volatility, the second and third columns give the values for the initial shock to banks and the last two columns describe the second part of the crisis that came with the economic downturn. 
Simple inspection of the table shows that countries can be roughly grouped into two categories. First, countries in the so-called core of the euro area were exposed to a considerable decline in profitability between the pre-crisis period and the first phase of the crisis. Subsequently the banking sectors in these countries recovered. This pattern can be observed for example in Austria, Belgium, the Netherlands, Germany France and Finland. Countries in the periphery on the other hand, started with higher levels of profitability which also declined, albeit less strongly, in the first phase of the crisis. These banking sectors, however, continued on the downward path as the domestic economies deteriorated. Figure 4 gives an illustration of these differences.

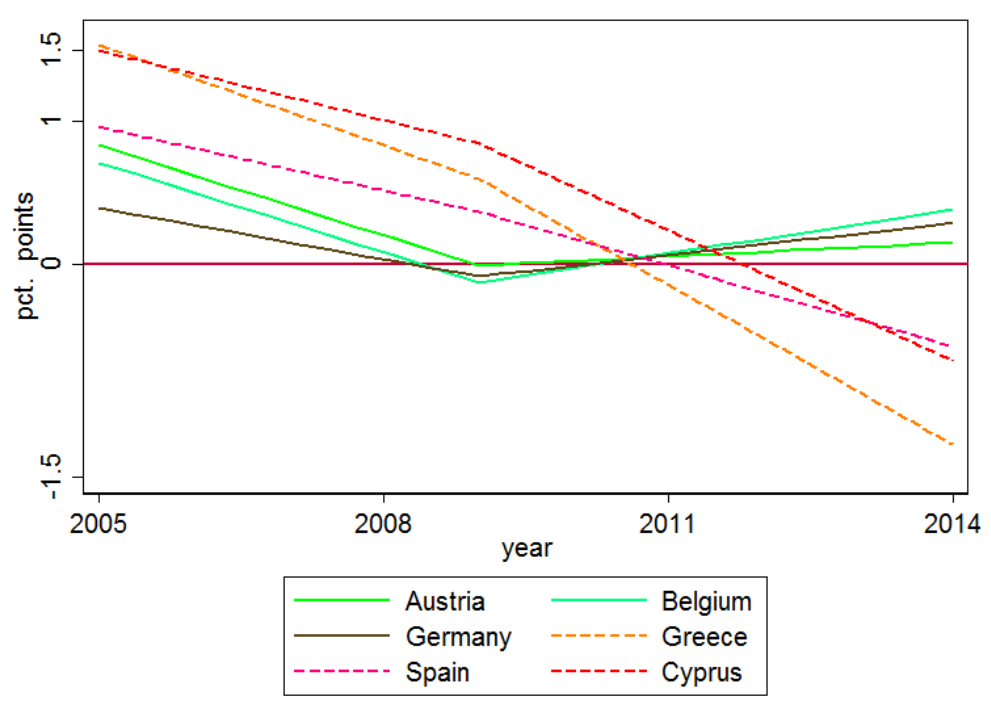

Figure 4: RoA developments in selected countries in the core and periphery of the euro area. Source: SnL Financial, own calculations.

In more detail, we observe considerable country heterogeneities regarding the evolution of bank profitability on the income and cost sides. For one, the importance of impairments in profitability mirrors the specific evolution of the crisis in 
different euro area countries. A number of countries experienced large "one-off" impairment costs that were concentrated in one particular year. Examples are Latvia and Lithuania in 2009 and Slovenia in 2013. These three countries experienced a severe domestic financial crisis triggered by the Global Financial Crisis. Latvia was the first European country to enter an IMF program in the ongoing financial crisis and Lithuania also was hit by the weakness in the baltics at that time. Slovenia was experiencing a collapse of growth in 2012 which hit the private sector and asset quality of banks. ${ }^{8}$ In countries in the euro area periphery by contrast the impact of impairment costs slowly compounds and peaks fairly late in the observation period in 2012. This development can be observed for example in Portugal, Italy, Ireland, Greece and Cyprus.

In 2012, there was a large debate on fragmentation and on the impact of funding costs on banks' profitability. In particular it was assumed that banks in the periphery would suffer strongly from increased funding costs as sovereign yields spiked. Nevertheless, from banks' profit and loss accounts, we do not see this in interest expenditures. In fact, interest expenditures were lower in peripheral countries throughout the sample period. The distance narrowed towards the end of the sample period but remained existent nonetheless. It is thus entirely possible that peripheral banks' profits were squeezed by the increase in funding costs. However, in our sample the interest expenses of peripheral banks generally did not increase over and above those of core countries' banks.

The reason for this difference in interest expenses is likely related to the larger reliance of peripheral country banks on retail deposits as a source of funding rather

\footnotetext{
${ }^{8}$ For a recount on the evolution of the crises in these countries, please see the IMF Article IV staff reports, available at http://www.imf.org.
} 


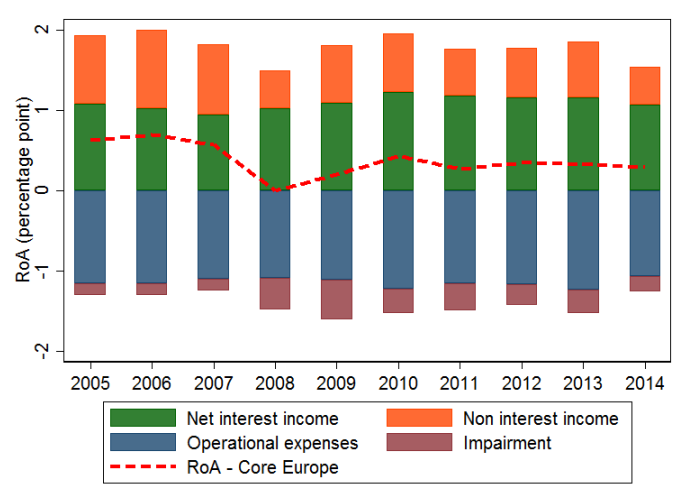

(a) Core euro area

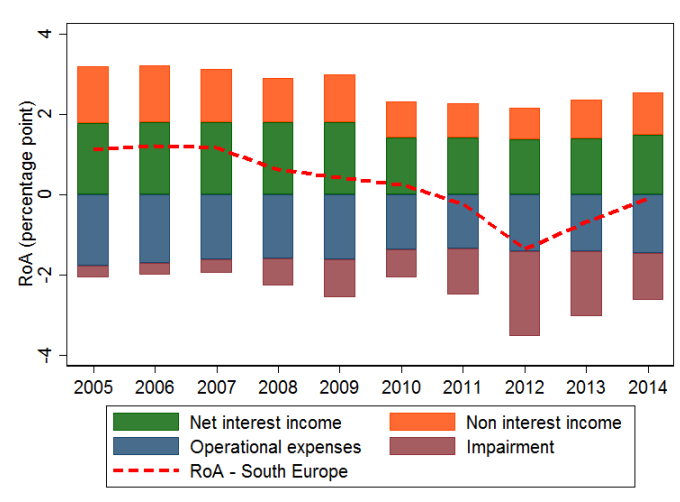

(b) Peripheral countries

Figure 5: Profitability decomposition in different sub-regions. Source: SnL Financial, own calculations.

than on wholesale issuance. With regard to developments of interest expenditures, both core and peripheral countries had a spike in 2008 (almost $5 \%$ of total assets for core countries and above $3 \%$ in the periphery). The standard deviation of interest expenses is much larger (more than double) in the core countries than in the periphery and exhibits two spikes in 2008 and in 2012. Again this is likely related to the volatility in wholesale funding markets during these periods. ${ }^{9}$

Figure 5 shows how impairments in the core euro area ${ }^{10}$ increased in 2008 and 2009 right after the events related to the original financial crisis in US subprime markets ocurred. In the euro area periphery ${ }^{11}$ on the other hand impairments remained more limited initially but exhibited considerable increases starting in 2011. It should be noted that throughout the crisis, pre-impairment profits were higher in the periphery than in the core euro area.

Generally speaking, profitability in terms of RoA seems to have been struc-

\footnotetext{
${ }^{9}$ For a detailed representation of these expenses see figure 10 in the annex.

${ }^{10}$ As core euro area we define France, Germany, Luxembourg, Belgium, Finland and Austria and the Netherlands.

${ }^{11}$ We define periphery as Greece, Ireland, Portugal, Spain and Italy.
} 
turally lower in core euro area countries before the crisis. Banks in the core tend to be more leveraged and do more high volume-low margin business. In Figure 5a it can also be seen that during the crisis net interest income remains fairly stable in the core while non interest income deteriorates - in particular in 2008-2009. This finding mirrors the volatility on this position that can be seen in Figure 3. By contrast, as can be seen in Figure 5b, in the periphery, all components of income are equally compressed starting from 2010. It should be noted that there is some adjustment on the cost side too as operating expenses decline around 2010. Clearly, banking sectors in these different areas were hit differently by the crisis and at different times.

The difference in business models could be responsible for the unequal impact of the crisis on different parts of the euro area. While core banks are larger and more active in capital markets, they depend more on trading income. This made them vulnerable to the immediate impact of the financial market turmoil and the confidence crisis in 2008 and 2009. For example, trading income not only declined but lowered profitability (over total assets) by $0.2 \%$ for core country banking sectors in 2008 (see Figure 2). Peripheral banks on the other hand, with more traditional retail oriented portfolios, suffered later in the context of the general economic downturn that started to unfold in 2009. These banks experienced a compression in all income categories paired with a strong increase of impairments in the loan portfolio.

Banks in the periphery accordingly exhibit a closer link with national economic developments. While lagged GDP growth exhibits a correlation of -0.16 with sector wide non-performing loans in core countries, this correlation becomes -0.53 in the 
peripheral countries.

\subsection{Discriminating by bank specific characteristics}

After examining some country heterogeneities, we analyse the impact of bank specific features below. We look at the evolution of bank profitability in terms of bank size, asset allocation and funding structure, ownership and capital adequacy.

With regard to the activity of banks we chose to distinguish banks by the risk weighted assets density. This measure is computed as the ratio of risk weighted assets to total assets $(R W A / T A)$ and typically gives an idea of whether a bank is retail oriented or capital markets oriented. Since retail loans will typically have higher risk weights than securities, banks with a high $R W A / T A$-ratio can be assumed to be more retail oriented, whereas banks with a low ratio tend to have more debt securities on their balance sheet. ${ }^{12}$ In our sample, the correlation of the $R W A / T A$-ratio with the ratio of gross customer loans over securities is 0.4 . In the periphery the correlation is even higher at 0.45 . Figure $6 \mathrm{a}$ shows that banks with a higher $R W A / T A$ - density are typically located in peripheral Europe.

When splitting the sample along the median of the risk weighted assets density, we observe that banks with a ratio above the median tend to have very high profitability from 2005 to 2007. These banks were also hit by the 2008 shock; the RoA was halved in 2008 (slightly above 0.5\%) and further dipped in 2009, it picked up in 2010 and 2011 before plummeting to very negative numbers in

\footnotetext{
${ }^{12}$ While many larger banks compute risk weights according to their internal models, the Standardised Approach (StA) can serve as a benchmark. According to StA risk weights for example, retail loans are weighted $75 \%$ while (corporate and bank) debt securities receive a maximum risk weight of $50 \%$ with a rating as low as A-. Sovereign exposures of European countries usually receive a $0 \%$ risk. In March 2015, the Basel committee issued a proposal to revise and adapt the standardised approach.
} 


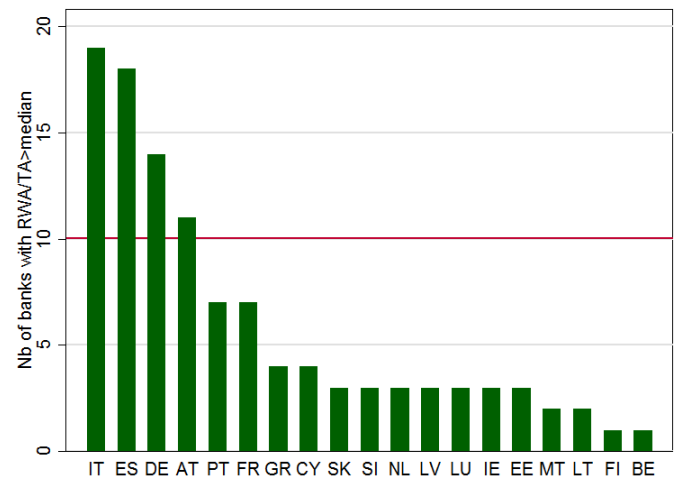

(a) Number of banks with high ratio

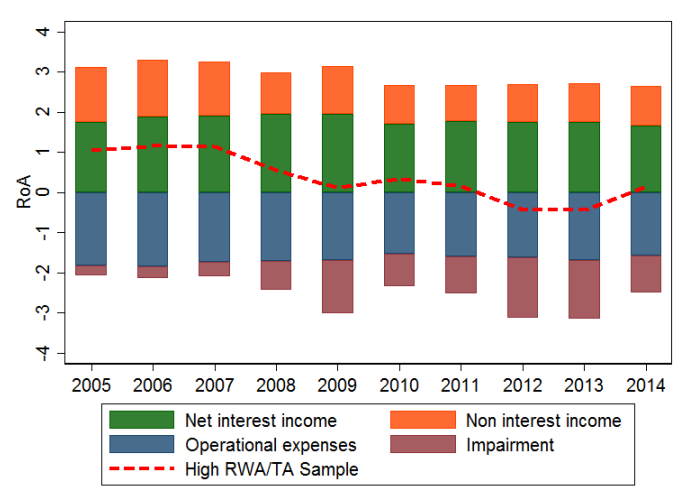

(b) Profitability of banks with high ratio

Figure 6: The risk weighted assets to total assets density ratio as a qualifier for the business model. Source: SnL Financial, own calculations.

2012 and 2013 (Figure 6b). Banks that have a ratio below the median, had a less volatile movement of their RoA. This reflects the fact that retail loans - which are more closely tied to domestic economic developments - retain a higher risk weight.

The main features of the evolution of bank profitability are also subject to the size of banks as measured by total assets. Small banks performed better before the global financial crisis; large banks recovered quickly after the crisis; and mediumsized banks performed the worst and have not recovered yet. The role of size, however, needs to be nuanced. Looking at banks' size in relation to the domestic banking sector, one can see that having a larger market share was advantageous in the years leading up to the crisis with average RoA slightly above that of smaller (relative to domestic peers) banks. After 2008, however, this advantage becomes much less clear.

In general, publicly owned banks ${ }^{13}$ on average did not experience a different

\footnotetext{
${ }^{13}$ When speaking of publicly owned banks we refer to all public banks including cooperative structures. We do not include banks that have come under public ownership after government recapitalisation during the crisis.
} 
evolution of profitability than other banks in our sample. To a large extent, controlling bank ownership is very close to controlling country groups, as publicly owned banks in our sample are concentrated in a few countries, notably Germany and France. The only notable difference is a slightly more pronounced decline in profits in 2008-09. This deviation is likely due to German and French banks in our sample of public banks which experienced severe losses from their securities portfolio in this period. This pattern in the evolution is similar to that observed for all core euro area banks as discussed above.

In the early stages of the crisis solvency was a widespread concern as the extent of losses was very uncertain across the board. The median non-core region banks slowly increased their regulatory capital ratio as early as 2008 but only reached $10 \%$ in 2011. The leverage ratio ${ }^{14}$ for the median non-core bank wavered around $6.5 \%$ before a noticeable increase in 2013 and 2014. For core country banks the median increase in the Tier 1 ratio was more pronounced. The leverage ratio on the other hand only moved up very slowly, reaching $4.99 \%$ in 2014 . Issuance activity in terms of the number of offerings was similar in both regions until 2009 when it peaked. After 2009, however, issuance dropped off in core countries whereas it remained elevated in the non-core region.

When bringing together solvency and profitability measures one can see that throughout the sample period banks with higher equity relative to their total assets have been more profitable on average (Figure 7a) than those that had a lower ratio. In particular, after 2008 these banks maintained positive profits on average. Banks with a lower equity over assets ratio exhibited negative profits in 2008-2009

\footnotetext{
${ }^{14}$ Please note that in this context we define the leverage ratio as the ratio of total equity over total assets. This concept should not be confused with the Basel 3 leverage ratio which divides equity by the exposure value and not total assets.
} 


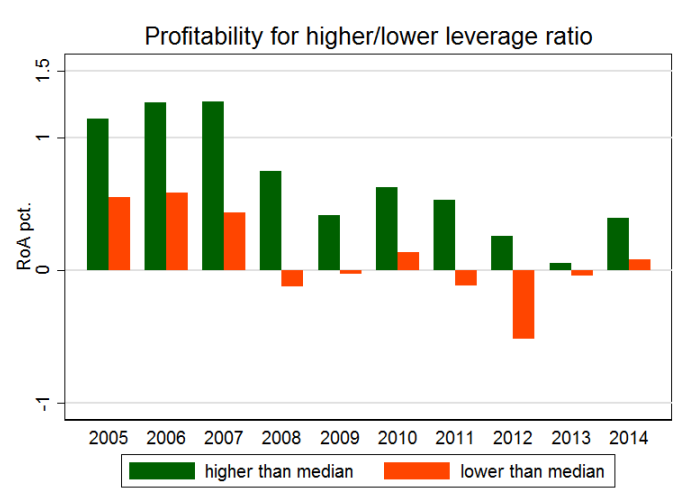

(a) Splitting by leverage ratio

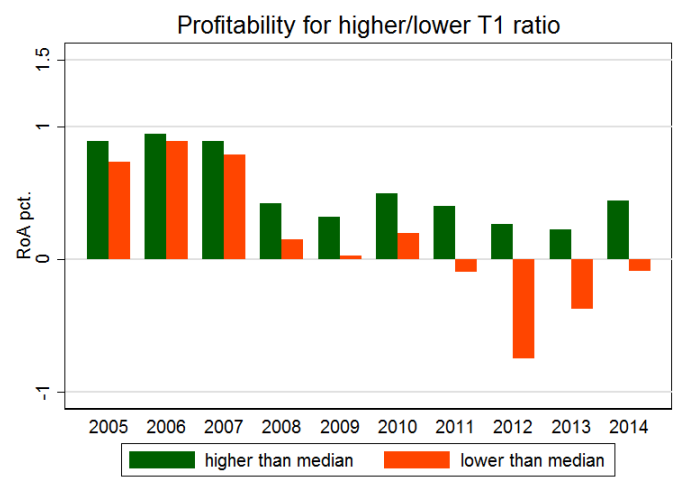

(b) Splitting by Tier 1 ratio

Figure 7: Profitability for banks with higher/lower solvency ratios than the median bank. Source: SnL Financial, own calculations.

and 2011-2013. This finding is interesting in the context of the discussion on the measure of return that is being used. ${ }^{15}$ Note that in commercial activity the return on equity is more frequently quoted. At the same time, leverage boosts return on equity which can hide the fact that the underlying assets held by a bank are less profitable per se.

Considering regulatory capital ratios the general picture remains unchanged. Figure $7 \mathrm{~b}$ shows profitability for banks with a Tier 1 capital ratio above and below the median bank in the sample. Initially profits behave very similar for both groups but starting in 2008 banks with a higher capital ratio perform better. Nevertheless, the group with lower T1 ratios only has negative profits starting in 2011.

Links between capitalisation and profitability can go both ways. A high profitability enables a bank to strengthen its capital position through internal capital generation. In reverse, in particular in times of crisis, losses on financial assets have to be covered by operating profits. If this is insufficient, the losses go into

\footnotetext{
${ }^{15}$ See our discussion in Section 2 on the primary measure used in this paper.
} 


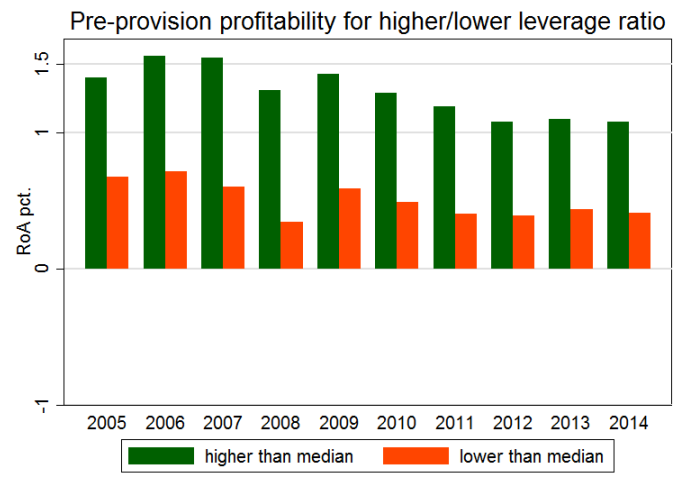

(a) Splitting by leverage ratio

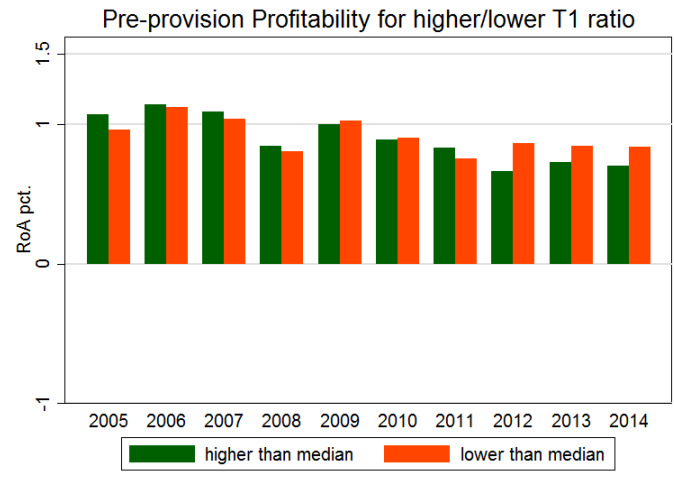

(b) Splitting by Tier 1 ratio

Figure 8: Pre-provision profitability for banks with higher/lower solvency ratios than the median bank. Source: SnL Financial, own calculations.

capital directly. At the same time banks with higher capital could be considered as being more risk averse in general. This could lead them to better manage risks in general and thus make safer loans which subsequently lead to less impairments (and hence better profitability).

Figure 8 shows pre-provision profitability developments for subsamples split by the level of equity over total assets and by the Tier 1 capital adequacy ratio. Panel 8a shows that banks with a higher leverage ratio than the median bank had a higher pre-provision profitability than banks with lower equity levels compared to their total assets. This means that banks with higher equity levels fared better throughout the crisis in terms of operational profitability, independent of impairment levels. The relationship disappears, however, when taking into account the Tier 1 ratio rather than the leverage measure. Considering that banks with a higher Tier 1 ratio do have a higher overall profitability (i.e. including costs from impairments) as shown in Figure 7b, this implies that these banks have had lower impairments. 
Overall, the summary statistics indicate that profitability did decline in the euro area as a whole over the period 2005-2014. The decline came in two waves, 2008-2009 and 2010-2012, which can also be geographically allocated. Regarding bank-specific characteristics, banks with a higher share of loans in their portfolio managed better in the initial stages of the crisis but suffered more later on. Higher equity levels have benefited banks throughout the crisis period. Nevertheless, the relationship with regulatory capital standards is somewhat less clear cut. While it can be said that banks with higher Tier 1 ratios performed better during the crisis, there is no discernible difference with regard to pre-impairment income.

We will now build on the results generated in this chapter in order to inform the subsequent econometric analysis.

\section{Econometric analysis}

Based on our data crunching exercise using the most recent financial statement data of banks, we have identified three main categories of factors that affect profits: 1) macroeconomic cycles and shocks, including both domestic factors and the overall risk appetite; 2) bank-specific characteristics, especially regarding banks' asset allocation, risk-weighted assets, funding and capital structures; and 3) the impact of recent regulation regarding capital requirements. In this section, we provide an econometric analysis of the determinants of bank profitability in the euro area as a support to the stylised facts observed in Section 3. 


\subsection{Model}

Indexing banks with $i$, countries with $s$ and years with $t$, our reduced-form estimation model is written as follows:

$$
\Pi_{i, t, s}=X_{i, t, s}^{\prime} \alpha+Z_{s, t}^{\prime} \beta+D^{\prime} \gamma+u_{i}+t+\epsilon_{i, t, s}
$$

$\prod_{i, s, t}$ denotes the net income or alternative income statement components of bank $i$ located in country $s$ (all cost components are expressed in negative terms). $X_{i, s, t}$ is a vector of bank-specific explanatory variables that reflect banks' asset allocation, funding structure and risk-taking behaviour. All other bank-specific variables are expressed as ratios in percentage points, except total assets that are calculated in $\log$ terms to control the size of the balance sheet. $Z_{s, t}$ is a vector of macroeconomic variables that are country-specific. GDP and CPI price index are expressed in growth rates while fiscal variables are expressed in percentages of GDP. $D$ is a vector of dummies that control country and year specificities, crisis events, as well as country groups that exhibit similar behaviours. $u_{i}$ is a timeinvariant bank fixed effect. $t$ refers to time dummies. The detailed list of variables used for the econometric analysis can be found in Table 9 in the annexe. $\epsilon_{i, t, s}$ is an error term. It is assumed that the error terms between banks in different countries are orthogonal while that among banks in a given country are correlated. This motivates us to use cluster standard errors (over country) for statistical inference.

The model is estimated using panel estimation methods. The Hausman test has been run and discriminates in favour of the fixed effect estimation. The Wooldgidge test that has also been used shows no first-order autocorrelation in the model. 


\subsection{Estimation results}

\subsubsection{Baseline results}

Table 4 presents the results of the baseline regression using the estimation equation (4), where $\Pi_{i t}$ is, in turn, net income, net interest income, non-interest income, and impairment expenses ${ }^{16}$, all scaled by lagged total assets. Alternative ways to decompose a bank's net income, as Equation (2) and (3) indicate, are tested as robustness checks and can be found in the annexe.

Regarding bank-specific features, we observe that a higher equity to total assets ratio raises profits across different income streams and lowers impairment expenses. One percentage point increase in Equity/T $A_{t-1}$ is associated with an increase in the net income to total assets ratio (RoA) by $0.174 \%$. This result also remains valid when we use regulatory capital (e.g. Core Tier 1 and Tier 1 capital, see Table 12 and Table 13) instead of total equity. Banks with higher regulatory capital performed on average better than their peers. This result shows the importance of having sufficient capital for profitability, in line with the spirit of Basel III capital requirements. Moreover, the risk-weighted assets to total assets ratio does not have a significant effect on net income but affects net interest income and net noninterest income. The marginal effect on net interest income is four times larger than on net non-interest income. An increase in $R W A_{t} / T A_{t-1}$ by one percentage point is associated with a 0.013 percentage point increase in net interest income over total assets, and 0.005 percentage point increase in non-interest income over total assets. Given the fact that banks with higher risk-weighted assets tend to be more specialised in traditional lending activities, it is reasonable that these banks

\footnotetext{
${ }^{16}$ Operating expenses are omitted as this component appears to be stable over time.
} 
have higher interest income and slightly higher non-interest income ${ }^{17}$. Finally, the loans to securities ratio significantly and positively affects net interest income although its economic significance is small.

Turning to the marginal effect of macroeconomic variables, GDP growth is associated with higher net income by significantly lowering impairment costs. In fact, in good times, when GDP growth is high, it is less likely for customer loans to be impaired. However, both net interest income and net non-interest income are not sensitive to the contemporaneous GDP growth. Moreover, net interest income is positively and significantly associated with the inflation rate. Furthermore, higher government debt over GDP lowers net income by 0.026 percentage point; this is mainly through lower net non-interest income (-0.008 percentage point) and higher impairment costs (-0.017 percentage point). Regarding higher impairment costs, this is because a higher public debt ratio would lower the creditworthiness of sovereign bonds and force banks to increase loan loss provisions. A higher sovereign debt ratio is also likely associated with more volatile financial markets and weak market confidence, leading to lower non-interest income (e.g. trading income). This result is confirmed by Table 11 where net trading income is isolated from the rest of income and expense streams.

Finally, we control for interbank market interest rates and global financial market volatility. Interbank market interest rates are negatively correlated with the RoA and positively correlated with impairment costs. This result is robust subject to different metrics of interbank market rates (e.g. EONIA rate or 3month EURIBOR rate). Global financial market volatility has a non-linear effect

\footnotetext{
${ }^{17}$ This is mostly related to fees and commissions. Table 11 in the annexe confirms that the coefficient of $R W A / T A_{t-1}$ is only significant for recurring income (sum of net interest income and income from fees and commissions).
} 
on all income and cost streams except net non-interest income.

Table 4: Baseline specification

\begin{tabular}{|c|c|c|c|c|}
\hline & $\begin{array}{c}(1) \\
\text { Net Income }\end{array}$ & $\begin{array}{c}(2) \\
\text { Net Interest Income }\end{array}$ & $\begin{array}{c}(3) \\
\text { Net Non-Interest Income }\end{array}$ & $\begin{array}{c}(4) \\
\text { Impairment }\end{array}$ \\
\hline $\log (\mathrm{TA})$ & $\begin{array}{l}0.0897 \\
(0.149)\end{array}$ & $\begin{array}{c}0.0535 \\
(0.0480)\end{array}$ & $\begin{array}{l}-0.0680 \\
(0.0914)\end{array}$ & $\begin{array}{l}0.0123 \\
(0.111)\end{array}$ \\
\hline Equity/TA(t-1) & $\begin{array}{l}0.174^{* * *} \\
(0.0403)\end{array}$ & $\begin{array}{c}0.0621 * * * \\
(0.0129)\end{array}$ & $\begin{array}{c}0.0601^{* * *} \\
(0.0172)\end{array}$ & $\begin{array}{c}-0.103^{* * *} \\
(0.0340)\end{array}$ \\
\hline Dep/WS & $\begin{array}{l}-0.000228 \\
(0.000288)\end{array}$ & $\begin{array}{c}0.0000271 \\
(0.0000545)\end{array}$ & $\begin{array}{c}0.0000127 \\
(0.0000502)\end{array}$ & $\begin{array}{c}0.000231 \\
(0.000266)\end{array}$ \\
\hline Loans/Secu & $\begin{array}{r}-0.00000520 \\
(0.0000406)\end{array}$ & $\begin{array}{c}0.0000178^{*} \\
(0.00000871)\end{array}$ & $\begin{array}{r}-0.000000585 \\
(0.00000882)\end{array}$ & $\begin{array}{c}0.0000220 \\
(0.0000413)\end{array}$ \\
\hline RWA/TA(t-1) & $\begin{array}{c}0.00436 \\
(0.00528)\end{array}$ & $\begin{array}{c}0.0128^{* * *} \\
(0.00235)\end{array}$ & $\begin{array}{c}0.00477^{* * *} \\
(0.00164)\end{array}$ & $\begin{array}{c}0.00299 \\
(0.00457)\end{array}$ \\
\hline$\triangle G D P$ & $\begin{array}{l}0.106^{* * *} \\
(0.0325)\end{array}$ & $\begin{array}{c}0.00662 \\
(0.00779)\end{array}$ & $\begin{array}{l}-0.00797 \\
(0.00784)\end{array}$ & $\begin{array}{c}-0.111^{* * *} \\
(0.0331)\end{array}$ \\
\hline Inflation & $\begin{array}{c}0.0830 \\
(0.0762)\end{array}$ & $\begin{array}{c}0.0451 * * * \\
(0.0151)\end{array}$ & $\begin{array}{c}-0.00244 \\
(0.0165)\end{array}$ & $\begin{array}{l}-0.0573 \\
(0.0649)\end{array}$ \\
\hline Gvt debt (\%GDP) & $\begin{array}{c}-0.0255^{* * *} \\
(0.00351)\end{array}$ & $\begin{array}{r}-0.000788 \\
(0.00193)\end{array}$ & $\begin{array}{c}-0.00815^{* * *} \\
(0.00184)\end{array}$ & $\begin{array}{c}0.0166^{* * *} \\
(0.00331)\end{array}$ \\
\hline Fiscal balance (\%GDP) & $\begin{array}{c}0.0199 \\
(0.0327)\end{array}$ & $\begin{array}{l}-0.00367 \\
(0.00624)\end{array}$ & $\begin{array}{c}-0.0124^{* *} \\
(0.00491)\end{array}$ & $\begin{array}{l}-0.0270 \\
(0.0267)\end{array}$ \\
\hline eonia & $\begin{array}{l}-0.170^{* *} \\
(0.0612)\end{array}$ & $\begin{array}{l}-0.0194 \\
(0.0323)\end{array}$ & $\begin{array}{c}0.0186 \\
(0.0267)\end{array}$ & $\begin{array}{c}0.148^{* * *} \\
(0.0499)\end{array}$ \\
\hline VIX & $\begin{array}{r}-0.139^{* *} \\
(0.0553)\end{array}$ & $\begin{array}{c}-0.0444^{*} \\
(0.0238)\end{array}$ & $\begin{array}{l}-0.0238 \\
(0.0226)\end{array}$ & $\begin{array}{c}0.101^{*} \\
(0.0539)\end{array}$ \\
\hline VIX2 & $\begin{array}{c}0.00334^{* *} \\
(0.00119)\end{array}$ & $\begin{array}{l}0.00115^{* *} \\
(0.000519)\end{array}$ & $\begin{array}{c}0.000132 \\
(0.000516)\end{array}$ & $\begin{array}{c}-0.00268^{* *} \\
(0.00118)\end{array}$ \\
\hline Constant & $\begin{array}{l}0.826 \\
(2.721) \\
\end{array}$ & $\begin{array}{l}-0.219 \\
(0.946)\end{array}$ & $\begin{array}{c}2.595 \\
(1.712)\end{array}$ & $\begin{array}{l}-1.383 \\
(2.022) \\
\end{array}$ \\
\hline Observations & 1388 & 1388 & 1388 & 1388 \\
\hline$R^{2}$ & 0.323 & 0.485 & 0.256 & 0.228 \\
\hline Adjusted $R^{2}$ & 0.317 & 0.481 & 0.250 & 0.221 \\
\hline r2_btw & 0.165 & 0.471 & 0.170 & 0.0660 \\
\hline rhocoeff & 0.630 & 0.835 & 0.779 & 0.631 \\
\hline \multicolumn{5}{|c|}{$\begin{array}{l}\text { Standard errors in parentheses } \\
\text { Standard deviation clustered over countries } \\
\text { Dependent variables are all scaled by Total Asset }(\mathrm{t}-1) \\
\text { No first-order autocorrelation by Wooldgidge test } \\
\text { Hausman test in favour of fixed effects } \\
{ }^{*} p<0.10,{ }^{* *} p<0.05,{ }^{* * *} p<0.01\end{array}$} \\
\hline
\end{tabular}

Our baseline regression results remain robust when we adopt alternative ways to decompose banks' profits and when we drop outliers. Table 10 provides a robustness check by separating pre-impairment profits from impairment costs. Table 11 distinguishes recurring from non-recurring profits. Table 14 excludes Baltic countries, as the banking crisis that Latvia and Lithuania experienced was a local crisis 
in nature and Estonia does not provide sufficient bank financial statement data from 2005 to 2007. Table 15, Table 16 and Table 17 exclude outliers based on statistical criteria, namely by dropping observations belonging to the top and bottom $1 \%(5 \%)$ of total observations of a number of selected variables.

\subsubsection{More on the impact of macroeconomic variables}

To push one step further Bolt et al. (2012)'s work, we argue that the impact of macroeconomic variables is not linear and depends on banks' business models. To test this hypothesis, we interact macroeconomic variables with variables that reflect banks' business models, namely the risk-weighted assets over total assets ratio, the deposit to whole sale funding ratio, the loans to securities ratio and the equity to total asset ratio $^{18}$. We illustrate this point using net income over total assets as dependent variable first.

In Table 5, we observe that conditional on the level of the risk-weighted asset ratio, the F-test indicates that macroeconomic variables (i.e. GDP growth and government debt ratio) and the interacted terms are jointly significant. The coefficients for other variables pertaining to bank-specific features remain robust as in the baseline regression. Figure 9 illustrates the marginal effect of contemporaneous GDP growth and that of government debt-to-GDP ratio conditional as a function of the level of the risk-weighted asset ratio (in decile). First, one can see that the marginal effect of our macroeconomic variables is significant at the $90 \%$ significance level for all values of $R W A / T A_{t-1}$ considered. The positive

\footnotetext{
${ }^{18}$ Only regressions using interaction with GDP growth and the government debt to GDP ratio generate joint significance for the variables of interest. Results using other interacted terms are available upon request.
} 


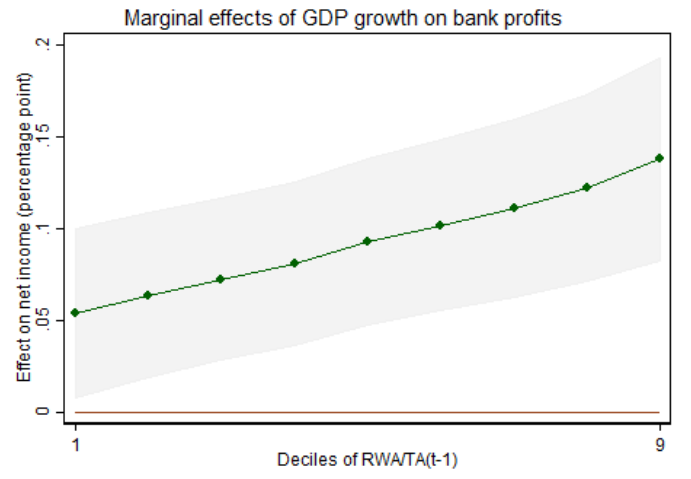

(a) GDP growth

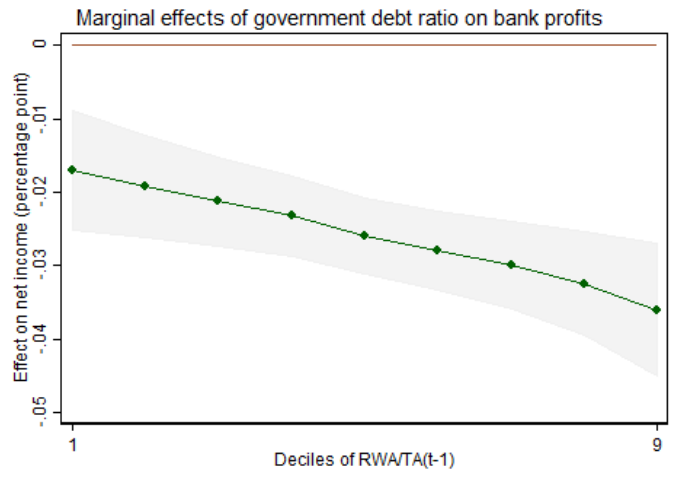

(b) Government debt ratio

Figure 9: Marginal effects with interacted terms

marginal impact of GDP growth is found to be more pronounced for banks with a high risk-weighted asset ratio. The negative marginal impact of the government debt ratio is also increasing in the risk-weighted asset ratio. One possible story underpinning these results is that a bank with higher $R W A / T A$ operates more in traditional deposit-lending activities which in turn are more likely to be affected by the growth perspective of the country in which the bank is located. Additional results using alternative dependent variables can be found in Table 18 and 19.

\subsubsection{Examining the impact of crisis shocks}

As we have seen in Section 3, European banks seem to have encountered two different types of shocks. The first shock was associated with the collapse of Lehman Brothers and affected banks' securities portfolio. The second shock was more related to the burst of credit bubbles in peripheral countries, slowing down the growth rate and leading to a subsequent surge in impairments.

In Table 6, we control these two types of external shocks by adding two dummy 
Table 5: Interacted macroeconomic variables

\begin{tabular}{|c|c|c|c|}
\hline & $\begin{array}{c}(1) \\
\text { Baseline }\end{array}$ & $\begin{array}{c}(2) \\
\text { Interacted GDP }\end{array}$ & $\begin{array}{c}(3) \\
\text { Interacted debt }\end{array}$ \\
\hline $\log (\mathrm{TA})$ & $\begin{array}{l}0.0897 \\
(0.149)\end{array}$ & $\begin{array}{c}0.103 \\
(0.149)\end{array}$ & $\begin{array}{c}0.123 \\
(0.137)\end{array}$ \\
\hline Equity/TA(t-1) & $\begin{array}{c}0.174 * * * \\
(0.0403)\end{array}$ & $\begin{array}{c}0.180^{* * *} \\
(0.0434)\end{array}$ & $\begin{array}{c}0.187^{* * *} \\
(0.0375)\end{array}$ \\
\hline Dep/WS & $\begin{array}{l}-0.000228 \\
(0.000288)\end{array}$ & $\begin{array}{l}-0.000223 \\
(0.000283)\end{array}$ & $\begin{array}{l}-0.000204 \\
(0.000301)\end{array}$ \\
\hline Loans/Secu & $\begin{array}{r}-0.00000520 \\
(0.0000406)\end{array}$ & $\begin{array}{r}-0.00000428 \\
(0.0000400)\end{array}$ & $\begin{array}{r}-0.00000488 \\
(0.0000401)\end{array}$ \\
\hline RWA/TA(t-1) & $\begin{array}{c}0.00436 \\
(0.00528)\end{array}$ & $\begin{array}{c}0.00215 \\
(0.00539)\end{array}$ & $\begin{array}{l}0.0260^{*} \\
(0.0124)\end{array}$ \\
\hline$\triangle G D P$ & $\begin{array}{l}0.106^{* * *} \\
(0.0325)\end{array}$ & $\begin{array}{c}0.0267 \\
(0.0315)\end{array}$ & $\begin{array}{c}0.0923 * * * \\
(0.0292)\end{array}$ \\
\hline Inflation & $\begin{array}{c}0.0830 \\
(0.0762)\end{array}$ & $\begin{array}{c}0.0652 \\
(0.0769)\end{array}$ & $\begin{array}{c}0.0558 \\
(0.0792)\end{array}$ \\
\hline Gvt debt (\%GDP) & $\begin{array}{c}-0.0255^{* * *} \\
(0.00351)\end{array}$ & $\begin{array}{c}-0.0256^{* * *} \\
(0.00327)\end{array}$ & $\begin{array}{l}-0.0109 \\
(0.00724)\end{array}$ \\
\hline Fiscal balance (\%GDP) & $\begin{array}{c}0.0199 \\
(0.0327)\end{array}$ & $\begin{array}{c}0.0197 \\
(0.0318)\end{array}$ & $\begin{array}{c}0.0139 \\
(0.0281)\end{array}$ \\
\hline eonia & $\begin{array}{c}-0.170^{* *} \\
(0.0612)\end{array}$ & $\begin{array}{l}-0.159^{* *} \\
(0.0586)\end{array}$ & $\begin{array}{c}-0.143^{* * *} \\
(0.0476)\end{array}$ \\
\hline VIX & $\begin{array}{l}-0.139^{* *} \\
(0.0553)\end{array}$ & $\begin{array}{l}-0.101^{*} \\
(0.0495)\end{array}$ & $\begin{array}{l}-0.0841 \\
(0.0633)\end{array}$ \\
\hline VIX2 & $\begin{array}{c}0.00334^{* *} \\
(0.00119)\end{array}$ & $\begin{array}{c}0.00251^{* *} \\
(0.00103)\end{array}$ & $\begin{array}{c}0.00211 \\
(0.00132)\end{array}$ \\
\hline$\Delta G D P^{*} \mathrm{RWA} / \mathrm{TA}(\mathrm{t}-1)$ & & $\begin{array}{r}0.00136^{* * *} \\
(0.000451)\end{array}$ & \\
\hline Gvt.Debt*RWA/TA(t-1) & & & $\begin{array}{c}-0.000307^{* *} \\
(0.000135)\end{array}$ \\
\hline Constant & $\begin{array}{c}0.826 \\
(2.721) \\
\end{array}$ & $\begin{array}{c}0.283 \\
(2.677) \\
\end{array}$ & $\begin{array}{l}-1.449 \\
(2.841) \\
\end{array}$ \\
\hline Observations & 1388 & 1388 & 1388 \\
\hline$R^{2}$ & 0.323 & 0.330 & 0.337 \\
\hline Adjusted $R^{2}$ & 0.317 & 0.324 & 0.330 \\
\hline Pvalue_macro & & 0.00237 & 0.000000450 \\
\hline Pvalue_RWA & & 0.0167 & 0.102 \\
\hline
\end{tabular}

Standard errors in parentheses

Standard deviation clustered over countries

Dependent variables are all scaled by Total Asset(t-1)

No first-order autocorrelation by Wooldgidge test

Hausman test in favour of fixed effects

${ }^{*} p<0.10,{ }^{* *} p<0.05,{ }^{* * *} p<0.01$ 
variables. Crisis 1 takes the value of one for any observations after 2008 (i.e. after the collapse of Lehman Brothers); Crisis1 is equal to zero otherwise. Crisis2, instead, takes the value of one for any observations after 2011.

In comparison with the baseline results, we observe that the main results highlighted in Table (4) remain valid, both in terms of the size and the significance of the coefficients. In addition, we observe that the 2008 shock dummy (i.e. collapse Lehman Brothers) strongly lowers banks' net non-interest income and slightly increases banks' net interest income. We argue that the 2008 crisis shock affected more net trading income (which is part of net non-interest income) via spillovers from US subprime markets and a breakdown in market confidence. Table 20 in the annexe confirms our reasoning. This table presents the same set of results as in Table 6 but isolates net trading income from the rest of income streams (labelled non-recurring income). Crisis2 dummy however is insignificant regardless of the dependent variable.

\subsubsection{Country specificities}

As our bank analysis in Section 3 demonstrates, there is large heterogeneity in banks' profitability across euro area countries. Here, we aim at providing econometric evidence on cross-country differences.

First, we run the baseline regression augmented by crisis dummies using separately the full sample, banks in core Europe ${ }^{19}$ and banks in peripheral Europe ${ }^{20}$. The results are presented in Table 7 . Several features deserve our attention. The

\footnotetext{
${ }^{19}$ Core Europe is defined in this paper to include Austria, Belgium, Germany, France, Finland, Luxembourg and Netherlands.

${ }^{20}$ Peripheral or south Europe is defined in this paper to include Cyprus, Greece, Italy, Ireland, Portugal and Spain.
} 
Table 6: Crisis shocks

\begin{tabular}{|c|c|c|c|c|}
\hline $\log (\mathrm{TA})$ & $\begin{array}{c}(1) \\
\text { Net Income } \\
0.111 \\
(0.163)\end{array}$ & $\begin{array}{c}(2) \\
\text { Net Interest Income } \\
0.0442 \\
(0.0500)\end{array}$ & $\begin{array}{c}(3) \\
\text { Net Non-Interest Income } \\
-0.0465 \\
(0.0754)\end{array}$ & $\begin{array}{c}(4) \\
\text { Impairment } \\
-0.00210 \\
(0.120)\end{array}$ \\
\hline Equity/TA(t-1) & $\begin{array}{c}0.176^{* * *} \\
(0.0411)\end{array}$ & $\begin{array}{c}0.0613^{* * *} \\
(0.0128)\end{array}$ & $\begin{array}{c}0.0622^{* * *} \\
(0.0179)\end{array}$ & $\begin{array}{c}0.104^{* * *} \\
(0.0341)\end{array}$ \\
\hline Dep/WS & $\begin{array}{c}-0.000216 \\
(0.000279)\end{array}$ & $\begin{array}{c}0.0000206 \\
(0.0000537)\end{array}$ & $\begin{array}{c}0.0000290 \\
(0.0000483)\end{array}$ & $\begin{array}{l}-0.000228 \\
(0.000261)\end{array}$ \\
\hline Loans/Secu & $\begin{array}{c}-0.00000637 \\
(0.0000405)\end{array}$ & $\begin{array}{l}0.0000182^{* *} \\
(0.00000852)\end{array}$ & $\begin{array}{l}-0.00000143 \\
(0.00000811)\end{array}$ & $\begin{array}{l}-0.0000228 \\
(0.0000412)\end{array}$ \\
\hline RWA/TA $(\mathrm{t}-1)$ & $\begin{array}{c}0.00290 \\
(0.00491)\end{array}$ & $\begin{array}{c}0.0135^{* * *} \\
(0.00227)\end{array}$ & $\begin{array}{l}0.00307^{*} \\
(0.00173)\end{array}$ & $\begin{array}{l}-0.00355 \\
(0.00424)\end{array}$ \\
\hline$\triangle G D P$ & $\begin{array}{c}0.114^{* * *} \\
(0.0335)\end{array}$ & $\begin{array}{c}0.00442 \\
(0.00852)\end{array}$ & $\begin{array}{l}-0.00398 \\
(0.00868)\end{array}$ & $\begin{array}{c}0.118^{* * *} \\
(0.0348)\end{array}$ \\
\hline Inflation & $\begin{array}{c}0.0754 \\
(0.0795)\end{array}$ & $\begin{array}{c}0.0471^{* * *} \\
(0.0142)\end{array}$ & $\begin{array}{c}-0.00605 \\
(0.0144)\end{array}$ & $\begin{array}{c}0.0511 \\
(0.0666)\end{array}$ \\
\hline Gvt debt (\%GDP) & $\begin{array}{c}-0.0218^{* * *} \\
(0.00368)\end{array}$ & $\begin{array}{l}-0.00256 \\
(0.00204)\end{array}$ & $\begin{array}{c}-0.00398^{*} \\
(0.00199)\end{array}$ & $\begin{array}{c}-0.0151^{* * *} \\
(0.00337)\end{array}$ \\
\hline Fiscal balance (\%GDP) & $\begin{array}{c}0.0263 \\
(0.0362)\end{array}$ & $\begin{array}{l}-0.00726 \\
(0.00547)\end{array}$ & $\begin{array}{c}-0.00359 \\
(0.00564)\end{array}$ & $\begin{array}{c}0.0287 \\
(0.0292)\end{array}$ \\
\hline eonia & $\begin{array}{c}-0.237^{* * *} \\
(0.0794)\end{array}$ & $\begin{array}{l}0.00599 \\
(0.0334)\end{array}$ & $\begin{array}{l}-0.0368 \\
(0.0376)\end{array}$ & $\begin{array}{c}-0.189^{* * *} \\
(0.0652)\end{array}$ \\
\hline VIX & $\begin{array}{c}-0.130^{* *} \\
(0.0611)\end{array}$ & $\begin{array}{c}-0.0506^{* *} \\
(0.0227)\end{array}$ & $\begin{array}{c}-0.00772 \\
(0.0201)\end{array}$ & $\begin{array}{c}-0.102 \\
(0.0594)\end{array}$ \\
\hline VIX2 & $\begin{array}{c}0.00362^{* *} \\
(0.00129)\end{array}$ & $\begin{array}{l}0.00114^{* *} \\
(0.000518)\end{array}$ & $\begin{array}{l}0.0000686 \\
(0.000407)\end{array}$ & $\begin{array}{c}0.00304^{* *} \\
(0.00131)\end{array}$ \\
\hline Crisis 1 & $\begin{array}{r}-0.496^{*} \\
(0.248)\end{array}$ & $\begin{array}{l}0.169^{* *} \\
(0.0717)\end{array}$ & $\begin{array}{c}-0.353^{* * *} \\
(0.105)\end{array}$ & $\begin{array}{l}-0.329 \\
(0.201)\end{array}$ \\
\hline Crisis2 & $\begin{array}{c}0.0491 \\
(0.0898)\end{array}$ & $\begin{array}{c}0.0215 \\
(0.0364)\end{array}$ & $\begin{array}{l}-0.0788 \\
(0.0579)\end{array}$ & $\begin{array}{c}0.102 \\
(0.0853)\end{array}$ \\
\hline Constant & $\begin{array}{c}0.409 \\
(3.038)\end{array}$ & $\begin{array}{c}-0.00619 \\
(0.965) \\
\end{array}$ & $\begin{array}{c}2.087 \\
(1.463) \\
\end{array}$ & $\begin{array}{l}1.236 \\
(2.204) \\
\end{array}$ \\
\hline Observations & 1388 & 1388 & 1388 & 1388 \\
\hline$R^{2}$ & 0.328 & 0.493 & 0.282 & 0.230 \\
\hline $\begin{array}{l}\text { Adjusted } R^{2} \\
\text { r2_btw }\end{array}$ & $\begin{array}{l}0.321 \\
0.191\end{array}$ & $\begin{array}{l}0.488 \\
0.455\end{array}$ & $\begin{array}{l}0.275 \\
0.258\end{array}$ & $\begin{array}{c}0.222 \\
0.0787\end{array}$ \\
\hline $\begin{array}{l}\text { r } 2 \text {-Dtw } \\
\text { rhocoeff }\end{array}$ & $\begin{array}{l}0.191 \\
0.605\end{array}$ & $\begin{array}{l}0.455 \\
0.838\end{array}$ & $\begin{array}{l}0.258 \\
0.765\end{array}$ & $\begin{array}{c}0.0787 \\
0.619\end{array}$ \\
\hline
\end{tabular}

Standard errors in parentheses

Standard deviation clustered over countries

Dependent variables are all scaled by Total Asset(t-1)

No first-order autocorrelation by Wooldgidge test

Hausman test in favour of fixed effects

${ }^{*} p<0.10,{ }^{* *} p<0.05,{ }^{* * *} p<0.01$ 
coefficient in front of $\triangle G D P$ is significant for banks in peripheral Europe and insignificant for those in core Europe. This should be related to the fact that banks in peripheral Europe are more traditional in their business model and that GDP growth is a key determinant of the quality of banks loans. The government debt ratio is also a significant determinant of banks' net income in peripheral Europe only. The short-term interbank market rate affects more net income in core Europe than in peripheral Europe because less traditional banks rely more on wholesale funding (e.g. interbank market funding) than customer deposits. Finally, the shock in 2008 associated with the collapse of Lehman Brothers affects only banks in core Europe.

These features can be once more confirmed if we decompose net income and look at the effects of the same set of explanatory variables on net interest income, net non-interest income and impairments in core and peripheral Europe. Results are presented in Table 8. The coefficient associated with $R W A / T A_{t-1}$ is positive and significant in both sub-samples when using net interest income over total assets as the dependent variable. The size and significance of the coefficient both are more pronounced in the peripheral Europe sub-sample. The goodness of fit in the peripheral Europe sub-sample is almost three times bigger than in the core Europe sub-sample. This is likely attributed to the fact that banks in peripheral Europe are more traditional in nature - absorbing deposits to make customer loans. Regarding non-interest income and impairments, $R W A / T A_{t-1}$ is only significant in the peripheral Europe sub-sample with the marginal effect on non-interest income half as important as on impairment expenses. This also confirms our hypothesis on the impact of the business model. The coefficient before $\triangle G D P$ is significant and positive only with respect to impairment expenses in both sub-samples. The 
one associated with the peripheral Europe sub-sample is four times bigger than that associated with the core Europe sub-sample. In terms of the impact of crisis shocks, the 2008 shock most affected the net non-interest income in core Europe. Crisis1 dummy lowers the net non-interest income in the core Europe sub-sample by 0.438 percentage point.

Table 7: RoA: Core vs. Peripheral Europe

\begin{tabular}{|c|c|c|c|}
\hline & $\begin{array}{l}\text { (1) } \\
\text { All }\end{array}$ & $\begin{array}{c}(2) \\
\text { Core }\end{array}$ & $\begin{array}{c}(3) \\
\text { South }\end{array}$ \\
\hline $\log (\mathrm{TA})$ & $\begin{array}{c}0.111 \\
(0.163)\end{array}$ & $\begin{array}{c}0.0522 \\
(0.0807)\end{array}$ & $\begin{array}{c}-0.0316 \\
(0.333)\end{array}$ \\
\hline Equity/TA(t-1) & $\begin{array}{c}0.176^{* * *} \\
(0.0411)\end{array}$ & $\begin{array}{c}0.115^{* * *} \\
(0.0294)\end{array}$ & $\begin{array}{l}0.210^{* *} \\
(0.0646)\end{array}$ \\
\hline Dep/WS & $\begin{array}{l}-0.000216 \\
(0.000279)\end{array}$ & $\begin{array}{c}0.000471 \\
(0.000303)\end{array}$ & $\begin{array}{l}-0.000434 \\
(0.000415)\end{array}$ \\
\hline Loans/Secu & $\begin{array}{c}-0.00000637 \\
(0.0000405)\end{array}$ & $\begin{array}{c}-0.00000510 \\
(0.0000983)\end{array}$ & $\begin{array}{c}-0.0000128 \\
(0.0000488)\end{array}$ \\
\hline RWA/TA(t-1) & $\begin{array}{c}0.00290 \\
(0.00491)\end{array}$ & $\begin{array}{c}0.00407 \\
(0.00261)\end{array}$ & $\begin{array}{l}-0.00376 \\
(0.00567)\end{array}$ \\
\hline$\triangle G D P$ & $\begin{array}{c}0.114^{* * *} \\
(0.0335)\end{array}$ & $\begin{array}{l}0.0270^{*} \\
(0.0125)\end{array}$ & $\begin{array}{c}0.0783^{* *} \\
(0.0283)\end{array}$ \\
\hline Inflation & $\begin{array}{c}0.0754 \\
(0.0795)\end{array}$ & $\begin{array}{c}0.0346 \\
(0.0207)\end{array}$ & $\begin{array}{l}0.0151 \\
(0.180)\end{array}$ \\
\hline Gvt debt (\%GDP) & $\begin{array}{c}-0.0218^{* * *} \\
(0.00368)\end{array}$ & $\begin{array}{c}0.00517 \\
(0.00568)\end{array}$ & $\begin{array}{c}-0.0213^{* * *} \\
(0.00457)\end{array}$ \\
\hline Fiscal balance (\%GDP) & $\begin{array}{c}0.0263 \\
(0.0362)\end{array}$ & $\begin{array}{c}0.0262 \\
(0.0315)\end{array}$ & $\begin{array}{l}0.00731 \\
(0.0395)\end{array}$ \\
\hline eonia & $\begin{array}{c}-0.237^{* * *} \\
(0.0794)\end{array}$ & $\begin{array}{l}-0.132^{*} \\
(0.0568)\end{array}$ & $\begin{array}{l}-0.0847 \\
(0.0866)\end{array}$ \\
\hline VIX & $\begin{array}{r}-0.130^{* *} \\
(0.0611)\end{array}$ & $\begin{array}{l}-0.0130 \\
(0.0299)\end{array}$ & $\begin{array}{l}-0.0274 \\
(0.135)\end{array}$ \\
\hline VIX2 & $\begin{array}{c}0.00362^{* *} \\
(0.00129)\end{array}$ & $\begin{array}{c}0.000504 \\
(0.000664)\end{array}$ & $\begin{array}{c}0.00125 \\
(0.00248)\end{array}$ \\
\hline Crisis1 & $\begin{array}{c}-0.496^{*} \\
(0.248)\end{array}$ & $\begin{array}{c}-0.685^{* * *} \\
(0.162)\end{array}$ & $\begin{array}{l}-0.491 \\
(0.565)\end{array}$ \\
\hline Crisis2 & $\begin{array}{c}0.0491 \\
(0.0898)\end{array}$ & $\begin{array}{l}-0.104 \\
(0.118)\end{array}$ & $\begin{array}{c}-0.000169 \\
(0.147)\end{array}$ \\
\hline Constant & $\begin{array}{c}0.409 \\
(3.038) \\
\end{array}$ & $\begin{array}{c}-0.992 \\
(1.670) \\
\end{array}$ & $\begin{array}{c}2.146 \\
(6.252) \\
\end{array}$ \\
\hline $\begin{array}{l}\text { Observations } \\
R^{2}\end{array}$ & $\begin{array}{l}1388 \\
0.328\end{array}$ & $\begin{array}{c}728 \\
0.274\end{array}$ & $\begin{array}{c}566 \\
0.371\end{array}$ \\
\hline Adjusted $R^{2}$ & 0.321 & 0.260 & 0.355 \\
\hline $\begin{array}{l}\text { r2_btw } \\
\text { rhocoeff }\end{array}$ & $\begin{array}{l}0.191 \\
0.605\end{array}$ & $\begin{array}{l}0.313 \\
0.491\end{array}$ & $\begin{array}{l}0.194 \\
0.609\end{array}$ \\
\hline $\begin{array}{l}\text { Standard errors in } \\
\text { Standard deviatio } \\
\text { Dependent variab } \\
\text { No first-order aut } \\
\text { Hausman test in } \\
{ }^{*} p<0.10,{ }^{* *} p<\end{array}$ & $\begin{array}{l}\text { parenthese } \\
\text { clustered } \\
\text { s are all sc } \\
\text { orrelation } \\
\text { vour of fix } \\
.05, * * * p\end{array}$ & $\begin{array}{l}\text { ver countr } \\
\text { led by To } \\
\text { by Wooldg } \\
\text { d effects } \\
0.01\end{array}$ & $\begin{array}{l}\text { Asset }(t-1) \\
\text { test }\end{array}$ \\
\hline
\end{tabular}


Table 8: Decomposition of profits: Core vs. Peripheral Europe

\begin{tabular}{|c|c|c|c|c|c|c|}
\hline $\log (\mathrm{TA})$ & $\begin{array}{c}\text { NII } \\
\text { Core } \\
0.0523 \\
(0.0522)\end{array}$ & $\begin{array}{c}\text { NII } \\
\text { South } \\
0.0558 \\
(0.0800)\end{array}$ & $\begin{array}{c}\begin{array}{c}\text { NonII } \\
\text { Core }\end{array} \\
0.0546 \\
(0.0750)\end{array}$ & $\begin{array}{c}\begin{array}{l}\text { NonII } \\
\text { South }\end{array} \\
-0.187 \\
(0.0963)\end{array}$ & $\begin{array}{c}\begin{array}{l}\text { IMP } \\
\text { Core }\end{array} \\
-0.102^{* *} \\
(0.0386)\end{array}$ & $\begin{array}{c}\text { IMP } \\
\text { South } \\
-0.0439 \\
(0.239)\end{array}$ \\
\hline Equity/TA(t-1) & $\begin{array}{c}0.0769^{* * *} \\
(0.0145)\end{array}$ & $\begin{array}{c}0.0522^{* *} \\
(0.0162)\end{array}$ & $\begin{array}{l}0.110^{* *} \\
(0.0407)\end{array}$ & $\begin{array}{c}0.0485 \\
(0.0246)\end{array}$ & $\begin{array}{c}0.0118 \\
(0.0101)\end{array}$ & $\begin{array}{l}0.142^{* *} \\
(0.0502)\end{array}$ \\
\hline Dep/WS & $\begin{array}{c}0.000757^{* *} \\
(0.000217)\end{array}$ & $\begin{array}{c}0.0000519 \\
(0.0000649)\end{array}$ & $\begin{array}{l}-0.000105 \\
(0.000419)\end{array}$ & $\begin{array}{c}0.00000829 \\
(0.0000759)\end{array}$ & $\begin{array}{c}0.000195^{*} \\
(0.0000896)\end{array}$ & $\begin{array}{l}-0.000467 \\
(0.000343)\end{array}$ \\
\hline Loans/Secu & $\begin{array}{l}0.0000636^{*} \\
(0.0000313)\end{array}$ & $\begin{array}{c}0.00000605 \\
(0.00000740)\end{array}$ & $\begin{array}{l}-0.0000121 \\
(0.0000659)\end{array}$ & $\begin{array}{c}-0.00000622 \\
(0.0000116)\end{array}$ & $\begin{array}{l}-0.0000485 \\
(0.0000512)\end{array}$ & $\begin{array}{l}-0.0000212 \\
(0.0000479)\end{array}$ \\
\hline RWA/TA(t-1) & $\begin{array}{c}0.00869^{* *} \\
(0.00275)\end{array}$ & $\begin{array}{c}0.0148^{* * *} \\
(0.00288)\end{array}$ & $\begin{array}{l}0.0000976 \\
(0.00244)\end{array}$ & $\begin{array}{c}0.00591^{* *} \\
(0.00187)\end{array}$ & $\begin{array}{c}0.0000597 \\
(0.00262)\end{array}$ & $\begin{array}{l}-0.0103^{*} \\
(0.00472)\end{array}$ \\
\hline$\triangle G D P$ & $\begin{array}{c}0.0161 \\
(0.0107)\end{array}$ & $\begin{array}{c}-0.0155 \\
(0.00852)\end{array}$ & $\begin{array}{c}0.00761 \\
(0.0110)\end{array}$ & $\begin{array}{l}-0.00309 \\
(0.0209)\end{array}$ & $\begin{array}{l}0.0190^{* *} \\
(0.00619)\end{array}$ & $\begin{array}{c}0.0980^{* *} \\
(0.0335)\end{array}$ \\
\hline Inflation & $\begin{array}{l}0.00783 \\
(0.0210)\end{array}$ & $\begin{array}{c}0.0232 \\
(0.0121)\end{array}$ & $\begin{array}{c}0.0457 \\
(0.0343)\end{array}$ & $\begin{array}{l}-0.0143 \\
(0.0258)\end{array}$ & $\begin{array}{c}0.0116 \\
(0.0333)\end{array}$ & $\begin{array}{l}0.0203 \\
(0.152)\end{array}$ \\
\hline Gvt debt (\%GDP) & $\begin{array}{c}0.00264 \\
(0.00395)\end{array}$ & $\begin{array}{c}-0.000258 \\
(0.00142)\end{array}$ & $\begin{array}{c}-0.0114 \\
(0.00672)\end{array}$ & $\begin{array}{l}-0.00706 \\
(0.00397)\end{array}$ & $\begin{array}{c}-0.00143 \\
(0.00528)\end{array}$ & $\begin{array}{l}-0.0128^{*} \\
(0.00612)\end{array}$ \\
\hline Fiscal balance (\%GDP) & $\begin{array}{l}0.00844 \\
(0.0169)\end{array}$ & $\begin{array}{c}-0.0134 \\
(0.00923)\end{array}$ & $\begin{array}{l}0.00576 \\
(0.0273)\end{array}$ & $\begin{array}{l}-0.0119^{*} \\
(0.00582)\end{array}$ & $\begin{array}{l}-0.00353 \\
(0.0203)\end{array}$ & $\begin{array}{c}0.0205 \\
(0.0330)\end{array}$ \\
\hline eonia & $\begin{array}{l}-0.0287 \\
(0.0399)\end{array}$ & $\begin{array}{c}0.0728^{* *} \\
(0.0275)\end{array}$ & $\begin{array}{c}-0.117 \\
(0.0735)\end{array}$ & $\begin{array}{l}0.00915 \\
(0.0500)\end{array}$ & $\begin{array}{l}-0.00509 \\
(0.0294)\end{array}$ & $\begin{array}{c}-0.138 \\
(0.0763)\end{array}$ \\
\hline VIX & $\begin{array}{l}-0.00264 \\
(0.0196)\end{array}$ & $\begin{array}{l}-0.0569 \\
(0.0317)\end{array}$ & $\begin{array}{l}-0.0374 \\
(0.0256)\end{array}$ & $\begin{array}{c}-0.0640^{*} \\
(0.0307)\end{array}$ & $\begin{array}{l}-0.00814 \\
(0.0424)\end{array}$ & $\begin{array}{l}0.0286 \\
(0.119)\end{array}$ \\
\hline VIX2 & $\begin{array}{c}0.000374 \\
(0.000446)\end{array}$ & $\begin{array}{c}0.00118 \\
(0.000759)\end{array}$ & $\begin{array}{c}0.000848 \\
(0.000743)\end{array}$ & $\begin{array}{c}0.00104 \\
(0.000756)\end{array}$ & $\begin{array}{l}0.0000615 \\
(0.000868)\end{array}$ & $\begin{array}{l}0.000321 \\
(0.00236)\end{array}$ \\
\hline Crisis1 & $\begin{array}{l}-0.0191 \\
(0.0888)\end{array}$ & $\begin{array}{c}0.0464 \\
(0.0856)\end{array}$ & $\begin{array}{c}-0.438^{*} \\
(0.183)\end{array}$ & $\begin{array}{r}-0.0211 \\
(0.170)\end{array}$ & $\begin{array}{c}-0.142 \\
(0.0902)\end{array}$ & $\begin{array}{l}-0.513 \\
(0.411)\end{array}$ \\
\hline Crisis2 & $\begin{array}{c}0.0303 \\
(0.0494)\end{array}$ & $\begin{array}{l}-0.0213 \\
(0.0410)\end{array}$ & $\begin{array}{l}-0.140 \\
(0.103)\end{array}$ & $\begin{array}{c}0.0532 \\
(0.0646)\end{array}$ & $\begin{array}{c}0.0374 \\
(0.0629)\end{array}$ & $\begin{array}{r}-0.0315 \\
(0.194)\end{array}$ \\
\hline Constant & $\begin{array}{l}-1.058 \\
(0.772) \\
\end{array}$ & $\begin{array}{l}-0.125 \\
(1.603)\end{array}$ & $\begin{array}{c}0.894 \\
(1.683) \\
\end{array}$ & $\begin{array}{c}5.288^{* *} \\
(1.844) \\
\end{array}$ & $\begin{array}{c}1.819^{* * *} \\
(0.443) \\
\end{array}$ & $\begin{array}{c}0.634 \\
(4.380) \\
\end{array}$ \\
\hline Observations & 728 & 566 & 728 & 566 & 728 & 566 \\
\hline$R^{2}$ & 0.274 & 0.689 & 0.285 & 0.373 & 0.165 & 0.248 \\
\hline $\begin{array}{l}\text { Adjusted } R^{2} \\
\text { r } 2 \text { btw }\end{array}$ & $\begin{array}{l}0.260 \\
0.486\end{array}$ & $\begin{array}{l}0.681 \\
0.368\end{array}$ & $\begin{array}{l}0.271 \\
0.257\end{array}$ & $\begin{array}{l}0.357 \\
0.210\end{array}$ & $\begin{array}{c}0.148 \\
0.000725\end{array}$ & $\begin{array}{c}0.229 \\
0.0891\end{array}$ \\
\hline rhocoeff & 0.773 & 0.860 & 0.745 & 0.809 & 0.593 & 0.574 \\
\hline
\end{tabular}

Standard errors in parentheses

Standard deviation clustered over countries

Dependent variables are all scaled by Total Asset(t-1)

No first-order autocorrelation by Wooldgidge test

Hausman test in favour of fixed effects

${ }^{*} p<0.10,{ }^{* *} p<0.05,{ }^{* * *} p<0.01$ 
Notice that we have also tried to control the ownership of a bank on bank profitability. This is to assess whether a publicly owned bank has significantly different evolution of profits in comparison with privately owned banks ${ }^{21}$. The results show that our dummy variable indicating the bank's ownership is to a large extent a statistical mimic of country differences. A large number of publicly owned banks are located in Germany and France.

Our econometric analysis seems to confirm our bank analysis in Section 3. In sum, bank specific features and macroeconomic conditions affect banks' profits. The marginal effects of these independent variables depend on the bank business model and the type of country where a bank is located. The differences in bank profitability and its determinants remain large in core Europe and peripheral Europe.

\section{Conclusion}

From our combined micro and macro analysis of bank profitability in the euro area, we conclude that banks' capital level, business model and macroeconomic conditions all matter to generate sustainable profits. The euro area has endured two different types of crisis shocks. The first shock mainly affected banks' securities portfolio and had a one-off impact. The second shock, associated with the unwinding of the European debt crisis, has had a long-lasting impact, significantly raising impairment costs of banks in peripheral Europe. We also find that the effects of macroeconomic conditions are not independent from bank business models.

\footnotetext{
${ }^{21}$ Results available upon request.
} 
The latter can amplify the marginal effects of the former on profitability.

If macroeconomic conditions happen to be cyclical and subject to external and unexpected shocks, efficient regulations can help banks to improve their capital level and guide them towards more efficient profit-generating models. In particular, we have found that a good capitalisation helps banks by protecting both their solvency and profitability in times of downturns. This gives additional prominence to the leverage ratio measure that has been introduced under Basel III.

Over the past few years, banks in the euro area have been increasing capital in response to increased uncertainty in financial markets and to counter solvency issues. Furthermore, banks' balance sheets have been de-risked and non-core businesses have been sold ${ }^{22}$. Going forward, business models will need to be adapted further to assure adequate profitability in a changed operating environment. In particular, regulatory changes will have an important bearing on the different components of banks' profits. The leverage ratio and new capital requirements will penalise size and lead to a reallocation of capital across activities.

Liquidity regulation will also affect bank profitability from both the asset and liability side of the balance sheet. This is an aspect that we have not studied in this paper. Liquidity regulation would likely induce banks to hold more very liquid securities of high quality. Also, Total Loss Absorption Capacity (TLAC) ${ }^{23}$ provisions will impose restrictions on bank funding and may make funding more market dependent, volatile and costly. The impact of this is not yet entirely clear and will motivate us for our further research.

\footnotetext{
${ }^{22}$ See for example ECB (2014).

${ }^{23}$ This term stems from the Financial Stability Board discussions on bailing in bank creditors in resolution. It describes a floor on bail-inable securities that banks will have to hold in their liability structure.
} 
In any case it will be important to monitor the convergence of national banking sectors going forward, as all these factors will be influenced by new regulation, harmonized resolution measures and common supervision. Some traditional sources of income will be restrained and banks will have to adapt. Their success in doing so will determine whether they will be successful in preserving their profitability. 


\section{References}

Albertazzi, U. and Gambacorta, L. (2009). Bank profitability and the business cycle. Journal of Financial Stability, 5(4):393 - 409.

Alessandri, P. and Nelson, B. D. (2015). Simple banking: Profitability and the yield curve. Journal of Money, Credit and Banking, 47(1):143-175.

Athanasoglou, P. P., Brissimis, S. N., and Delis, M. D. (2008). Bank-specific, industry-specific and macroeconomic determinants of bank profitability. Journal of International Financial Markets, Institutions and Money, 18(2):121 - 136.

Ayadi, R., Naceur, S. B., Casu, B., and Quinn, B. (2015). Does Basel compliance matter for bank performance? Working papers WP/15/100, International Monetary Fund.

Barth, J. R., Lin, C., Ma, Y., Seade, J., and Song, F. M. (2013). Do bank regulation, supervision and monitoring enhance or impede bank efficiency? Journal of Banking and Finance, 37(8):2879 - 2892.

Bikker, J. A. and Hu, H. (2002). Cyclical patterns in profits, provisioning and lending of banks and procyclicality of the new Basel capital requirements. Banca Nazionale del Lavoro Quarterly Review, 55(221):143-175.

Bolt, W., de Haan, L., Hoeberichts, M., van Oordt, M. R., and Swank, J. (2012). Bank profitability during recessions. Journal of Banking and Finance, 36(9):2552 $-2564$.

Bouvatier, V. and Lepetit, L. (2008). Banks' procyclical behavior: Does provi- 
sioning matter? Journal of International Financial Markets, Institutions and Money, 18(5):513 - 526.

Demirguc-Kunt, A. and Huizinga, H. (2000). Determinants of commercial bank interest margins and profitability: Some interntional evidence. The World Bank Economic Review, 13(2):379-408.

ECB (2014). Banking structures report 2014. Technical report, European Central Bank, Frankfurt am Main.

ECB (2015). Financial Stability Review. ECB policy papers, European Central Bank.

Erce, A. (2015). Bank and sovereign risk feedback loops. Globalization and Monetary Policy Institute Working Paper 227, Federal Reserve Bank of Dallas.

Hanson, S. G., Kashyap, A. K., and Stein, J. C. (2011). A macroprudential approach to financial regulation. Journal of Economic Perspectives, 25(1):328.

IMF (2014). Global financial stability report. Technical report, International Monetary Fund, Washington DC.

Jian, G., Tang, N., Law, E., and Sze, A. (2003). Determinants of bank profitability in hong kong. Hong Kong Monetary Authority Research Memorandum.

Laeven, L. and Majnoni, G. (2003). Loan loss provisioning and economic slowdowns: too much, too late? Journal of Financial Intermediation, 12(2):178 197. Special Issue for the Federal Reserve Bank of Boston. 
Roengpitya, R., Tarashev, N., and Tsatsaronis, K. (2014). Bank business models. BIS Quarterly Review, pages 55-65. 


\section{A Annex}

\section{A.1 Variables and descriptive statistics}

Table 9: Variable definitions and data sources

\begin{tabular}{|c|c|c|c|}
\hline Variable & Symbol & Definition & Source \\
\hline Net income & NI & scaled by total assets $t-1$ & SNL \\
\hline Net interest income & NII & scaled by total assets $t-1$ & SNL \\
\hline $\begin{array}{l}\text { Net fees and commissions } \\
\text { income }\end{array}$ & NFCI & scaled by total assets $t-1$ & SNL \\
\hline Net trading income & NTI & scaled by total assets $t-1$ & SNL \\
\hline Other net income & ONI & scaled by total assets $t-1$ & SNL \\
\hline Operating expenses & $\mathrm{OE}$ & scaled by total assets $t-1$ & SNL \\
\hline Impairment expenses & IMP & scaled by total assets $t-1$ & SNL \\
\hline Non interest income & NonII & $\begin{array}{l}(\mathrm{NFCI}+\mathrm{NTI}+\mathrm{ONI}) \text { scaled by } \\
\text { total assets } t-1\end{array}$ & SNL \\
\hline Total assets $(\log )$ & $\log (\mathrm{TA})$ & $\begin{array}{l}\text { used to control the size of the } \\
\text { balance sheet }\end{array}$ & SNL \\
\hline Equity ratio & Equity $/ T A_{t-1}$ & scaled by total assets $t-1$ & SNL \\
\hline $\begin{array}{l}\text { Deposits to wholesale } \\
\text { funding ratio }\end{array}$ & $D e p / W S$ & measure of funding structure & SNL \\
\hline Loans to securities ratio & Loans/Secu & measure of asset allocation & SNL \\
\hline Risk weighted asset ratio & $R W A / T A_{t-1}$ & $\begin{array}{l}\text { measure of the size of risk } \\
\text { weighted assets }\end{array}$ & SNL \\
\hline Real GDP growth & $\triangle G D P$ & $\left(G D P_{t} / G D P_{t-1}-1\right)$ & $\begin{array}{l}\text { IMF } \\
\text { WEO }\end{array}$ \\
\hline Inflation & Inflation & changes in CPI price index & $\begin{array}{l}\text { IMF } \\
\text { WEO }\end{array}$ \\
\hline Public debt & Gvt debt & $\begin{array}{l}\text { Government debt divided by } \\
\text { nominal GDP (percentage point) }\end{array}$ & $\begin{array}{l}\text { IMF } \\
\text { WEO }\end{array}$ \\
\hline Public deficit & Fiscal balance & $\begin{array}{l}\text { Fiscal balanced divided by nom- } \\
\text { inal GDP (percentage point) }\end{array}$ & $\begin{array}{l}\text { IMF } \\
\text { WEO }\end{array}$ \\
\hline EONIA & eonia & $\begin{array}{l}\text { Benchmark interbank market } \\
\text { rate }\end{array}$ & $\mathrm{ECB}$ \\
\hline Fin. market volatility & VIX & VIX index & Bloomberg \\
\hline
\end{tabular}




\section{A.2 Additional graphs}

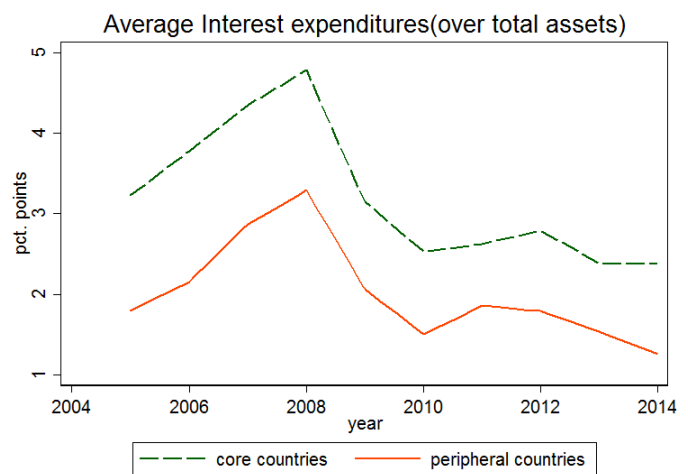

(a) Average

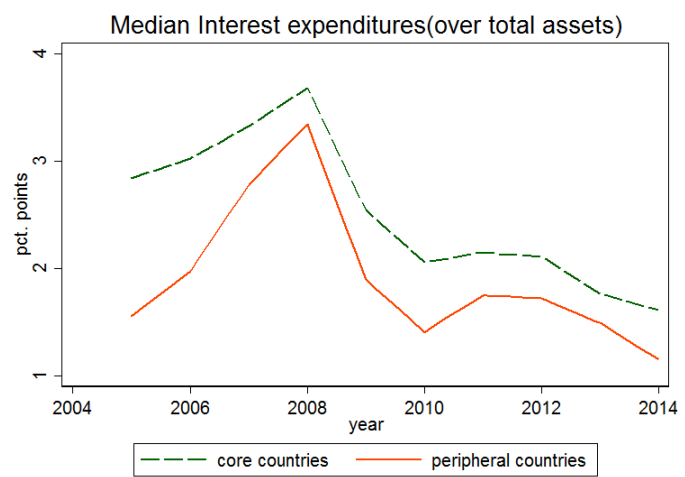

(b) Median

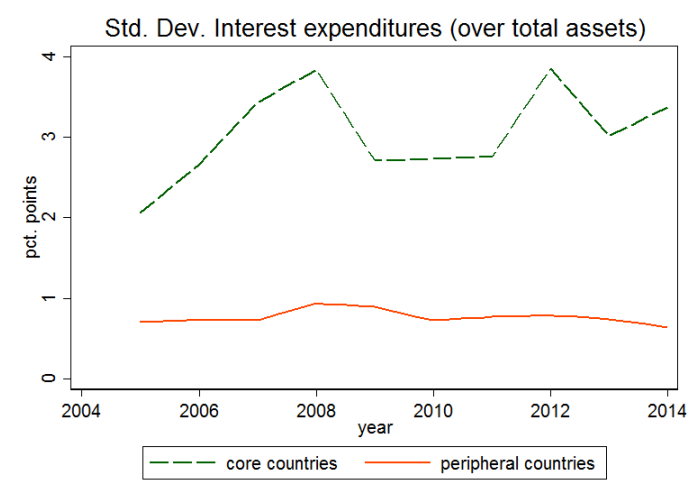

(c) Standard deviation

Figure 10: Interest expenditure of sample banks over total assets. Source: SnL Financial, own calculations. 


\section{A.3 Additional results}

\section{A.3.1 Robustness checks with respect to the baseline regression}

Table 10: Alternative decomposition of profits

\begin{tabular}{|c|c|c|c|}
\hline & $\begin{array}{l}(1) \\
\text { Net Income }\end{array}$ & $\begin{array}{c}(2) \\
\text { Pre-impairment Income }\end{array}$ & $\begin{array}{c}(3) \\
\text { Impairment }\end{array}$ \\
\hline $\log (\mathrm{TA})$ & $\begin{array}{l}0.0897 \\
(0.149)\end{array}$ & $\begin{array}{c}0.0969 \\
(0.0598)\end{array}$ & $\begin{array}{c}-0.0123 \\
(0.111)\end{array}$ \\
\hline Equity/TA(t-1) & $\begin{array}{c}0.174^{* * *} \\
(0.0403)\end{array}$ & $\begin{array}{c}0.0779^{* * *} \\
(0.0134)\end{array}$ & $\begin{array}{r}0.103^{* * *} \\
(0.0340)\end{array}$ \\
\hline Dep/WS & $\begin{array}{l}-0.000228 \\
(0.000288)\end{array}$ & $\begin{array}{c}-0.00000760 \\
(0.0000637)\end{array}$ & $\begin{array}{l}-0.000231 \\
(0.000266)\end{array}$ \\
\hline Loans/Secu & $\begin{array}{r}-0.00000520 \\
(0.0000406)\end{array}$ & $\begin{array}{c}0.0000152^{* * *} \\
(0.00000498)\end{array}$ & $\begin{array}{l}-0.0000220 \\
(0.0000413)\end{array}$ \\
\hline RWA/TA(t-1) & $\begin{array}{c}0.00436 \\
(0.00528)\end{array}$ & $\begin{array}{c}0.00658^{* * *} \\
(0.00152)\end{array}$ & $\begin{array}{l}-0.00299 \\
(0.00457)\end{array}$ \\
\hline$\triangle G D P$ & $\begin{array}{c}0.106^{* * *} \\
(0.0325)\end{array}$ & $\begin{array}{l}-0.00574 \\
(0.00640)\end{array}$ & $\begin{array}{l}0.111^{* * *} \\
(0.0331)\end{array}$ \\
\hline Inflation & $\begin{array}{c}0.0830 \\
(0.0762)\end{array}$ & $\begin{array}{c}0.0240 \\
(0.0201)\end{array}$ & $\begin{array}{c}0.0573 \\
(0.0649)\end{array}$ \\
\hline Gvt debt (\%GDP) & $\begin{array}{c}-0.0255^{* * *} \\
(0.00351)\end{array}$ & $\begin{array}{l}-0.00925 * * * \\
(0.00151)\end{array}$ & $\begin{array}{c}-0.0166^{* * *} \\
(0.00331)\end{array}$ \\
\hline Fiscal balance (\%GDP) & $\begin{array}{c}0.0199 \\
(0.0327)\end{array}$ & $\begin{array}{l}-0.00792 \\
(0.00879)\end{array}$ & $\begin{array}{c}0.0270 \\
(0.0267)\end{array}$ \\
\hline eonia & $\begin{array}{r}-0.170^{* *} \\
(0.0612)\end{array}$ & $\begin{array}{l}-0.0160 \\
(0.0255)\end{array}$ & $\begin{array}{c}-0.148^{* * *} \\
(0.0499)\end{array}$ \\
\hline VIX & $\begin{array}{r}-0.139^{* *} \\
(0.0553)\end{array}$ & $\begin{array}{l}-0.0252 \\
(0.0263)\end{array}$ & $\begin{array}{l}-0.101^{*} \\
(0.0539)\end{array}$ \\
\hline VIX2 & $\begin{array}{c}0.00334^{* *} \\
(0.00119)\end{array}$ & $\begin{array}{c}0.000391 \\
(0.000537)\end{array}$ & $\begin{array}{c}0.00268^{* *} \\
(0.00118)\end{array}$ \\
\hline Constant & $\begin{array}{c}0.826 \\
(2.721) \\
\end{array}$ & $\begin{array}{l}-0.574 \\
(0.998) \\
\end{array}$ & $\begin{array}{c}1.383 \\
(2.022) \\
\end{array}$ \\
\hline $\begin{array}{l}\text { Observations } \\
R^{2}\end{array}$ & $\begin{array}{l}1388 \\
0.323\end{array}$ & $\begin{array}{l}1388 \\
0.272\end{array}$ & $\begin{array}{l}1388 \\
0.228\end{array}$ \\
\hline Adjusted $R^{2}$ & 0.317 & 0.265 & 0.221 \\
\hline $\begin{array}{l}\text { r2_btw } \\
\text { rhocoeff }\end{array}$ & $\begin{array}{l}0.165 \\
0.630\end{array}$ & $\begin{array}{l}0.380 \\
0.657\end{array}$ & $\begin{array}{c}0.0660 \\
0.631\end{array}$ \\
\hline \multicolumn{4}{|c|}{$\begin{array}{l}\text { Standard errors in parentheses } \\
\text { Standard deviation clustered over countries } \\
\text { Dependent variables are all scaled by Total Asset }(\mathrm{t}-1) \\
\text { No first-order autocorrelation by Wooldgidge test } \\
\text { Hausman test in favour of fixed effects } \\
{ }^{*} p<0.10,{ }^{* *} p<0.05,{ }^{* * *} p<0.01\end{array}$} \\
\hline
\end{tabular}


Table 11: Alternative decomposition of profits

\begin{tabular}{|c|c|c|c|c|}
\hline $\log (\mathrm{TA})$ & $\begin{array}{c}(1) \\
\text { Net Income } \\
0.0897 \\
(0.149)\end{array}$ & $\begin{array}{c}(2) \\
\text { Recurring Income } \\
-0.0185 \\
(0.0817)\end{array}$ & $\begin{array}{c}(3) \\
\text { Non Recurring Income } \\
0.0717 \\
(0.0739)\end{array}$ & $\begin{array}{c}(4) \\
\text { Impairment } \\
-0.0123 \\
(0.111)\end{array}$ \\
\hline Equity/TA(t-1) & $\begin{array}{c}0.174^{* * *} \\
(0.0403)\end{array}$ & $\begin{array}{c}0.0934^{* * *} \\
(0.0165)\end{array}$ & $\begin{array}{c}0.00680 \\
(0.00537)\end{array}$ & $\begin{array}{c}0.103^{* * *} \\
(0.0340)\end{array}$ \\
\hline Dep/WS & $\begin{array}{c}-0.000228 \\
(0.000288)\end{array}$ & $\begin{array}{c}0.0000176 \\
(0.0000574)\end{array}$ & $\begin{array}{c}0.0000433 \\
(0.0000651)\end{array}$ & $\begin{array}{c}-0.000231 \\
(0.000266)\end{array}$ \\
\hline Loans/Secu & $\begin{array}{r}-0.00000520 \\
(0.0000406)\end{array}$ & $\begin{array}{c}0.0000223^{* * *} \\
(0.00000687)\end{array}$ & $\begin{array}{l}-0.00000360 \\
(0.00000490)\end{array}$ & $\begin{array}{c}-0.0000220 \\
(0.0000413)\end{array}$ \\
\hline RWA/TA(t-1) & $\begin{array}{c}0.00436 \\
(0.00528)\end{array}$ & $\begin{array}{c}0.0159^{* * *} \\
(0.00243)\end{array}$ & $\begin{array}{c}0.00225 \\
(0.00172)\end{array}$ & $\begin{array}{l}-0.00299 \\
(0.00457)\end{array}$ \\
\hline$\triangle G D P$ & $\begin{array}{c}0.106^{* * *} \\
(0.0325)\end{array}$ & $\begin{array}{c}0.00678 \\
(0.00822)\end{array}$ & $\begin{array}{c}-0.00325 \\
(0.0101)\end{array}$ & $\begin{array}{c}0.111^{* * *} \\
(0.0331)\end{array}$ \\
\hline Inflation & $\begin{array}{c}0.0830 \\
(0.0762)\end{array}$ & $\begin{array}{c}0.0487^{* * *} \\
(0.0114)\end{array}$ & $\begin{array}{c}-0.00563 \\
(0.0112)\end{array}$ & $\begin{array}{c}0.0573 \\
(0.0649)\end{array}$ \\
\hline Gvt debt (\%GDP) & $\begin{array}{c}-0.0255^{* * *} \\
(0.00351)\end{array}$ & $\begin{array}{l}-0.00247 \\
(0.00238)\end{array}$ & $\begin{array}{c}-0.00468^{* *} \\
(0.00177)\end{array}$ & $\begin{array}{c}-0.0166^{* * *} \\
(0.00331)\end{array}$ \\
\hline Fiscal balance (\%GDP) & $\begin{array}{c}0.0199 \\
(0.0327)\end{array}$ & $\begin{array}{c}-0.00344 \\
(0.00784)\end{array}$ & $\begin{array}{l}-0.0100^{*} \\
(0.00512)\end{array}$ & $\begin{array}{c}0.0270 \\
(0.0267)\end{array}$ \\
\hline eonia & $\begin{array}{c}-0.170^{* *} \\
(0.0612)\end{array}$ & $\begin{array}{c}-0.00661 \\
(0.0328)\end{array}$ & $\begin{array}{l}-0.0457 \\
(0.0279)\end{array}$ & $\begin{array}{c}-0.148^{* * *} \\
(0.0499)\end{array}$ \\
\hline VIX & $\begin{array}{c}-0.139^{* *} \\
(0.0553)\end{array}$ & $\begin{array}{c}-0.0414^{*} \\
(0.0237)\end{array}$ & $\begin{array}{l}-0.0325 \\
(0.0215)\end{array}$ & $\begin{array}{l}-0.101^{*} \\
(0.0539)\end{array}$ \\
\hline VIX2 & $\begin{array}{c}0.00334^{* *} \\
(0.00119)\end{array}$ & $\begin{array}{l}0.00104^{*} \\
(0.000517)\end{array}$ & $\begin{array}{c}0.000405 \\
(0.000504)\end{array}$ & $\begin{array}{c}0.00268^{* *} \\
(0.00118)\end{array}$ \\
\hline Constant & $\begin{array}{c}0.826 \\
(2.721)\end{array}$ & $\begin{array}{l}1.449 \\
(1.453)\end{array}$ & $\begin{array}{l}-0.429 \\
(1.359)\end{array}$ & $\begin{array}{c}1.383 \\
(2.022)\end{array}$ \\
\hline Observations & 1388 & 1388 & 1388 & 1388 \\
\hline$R^{2}$ & 0.323 & 0.554 & 0.056 & 0.228 \\
\hline Adjusted $R^{2}$ & 0.317 & 0.550 & 0.048 & 0.221 \\
\hline $\begin{array}{l}\text { r2_btw } \\
\text { rhocoeff }\end{array}$ & $\begin{array}{l}0.165 \\
0.630\end{array}$ & $\begin{array}{l}0.449 \\
0.888\end{array}$ & $\begin{array}{c}0.0519 \\
0.264\end{array}$ & $\begin{array}{c}0.0660 \\
0.631\end{array}$ \\
\hline
\end{tabular}

Standard errors in parentheses

Standard deviation clustered over countries

Dependent variables are all scaled by Total Asset(t-1)

No first-order autocorrelation by Wooldgidge test

Hausman test in favour of fixed effects

${ }^{*} p<0.10,{ }^{* *} p<0.05,{ }^{* * *} p<0.01$ 


\section{A.3.2 Robustness check using regulatory capital}

Table 12: Baseline regression using Tier 1 capital

\begin{tabular}{|c|c|c|c|c|}
\hline & $\begin{array}{c}(1) \\
\text { Net Income }\end{array}$ & $\begin{array}{c}(2) \\
\text { Net Interest Income }\end{array}$ & $\begin{array}{c}(3) \\
\text { Net Non-Interest Income }\end{array}$ & $\begin{array}{c}(4) \\
\text { Impairment }\end{array}$ \\
\hline $\log (\mathrm{TA})$ & $\begin{array}{c}-0.0232 \\
(0.115)\end{array}$ & $\begin{array}{c}0.0225 \\
(0.0506)\end{array}$ & $\begin{array}{c}-0.100 \\
(0.0945)\end{array}$ & $\begin{array}{l}-0.0771 \\
(0.0877)\end{array}$ \\
\hline $\mathrm{T} 1 / \operatorname{RWA}(\mathrm{t}-1)$ & $\begin{array}{r}0.0455^{* * *} \\
(0.00767)\end{array}$ & $\begin{array}{r}0.0170^{* * *} \\
(0.00410)\end{array}$ & $\begin{array}{c}0.00648 \\
(0.00591)\end{array}$ & $\begin{array}{r}0.0314^{* * *} \\
(0.00869)\end{array}$ \\
\hline Dep/WS & $\begin{array}{l}-0.000126 \\
(0.000349)\end{array}$ & $\begin{array}{c}0.0000759 \\
(0.0000482)\end{array}$ & $\begin{array}{c}0.0000845 \\
(0.0000613)\end{array}$ & $\begin{array}{l}-0.000196 \\
(0.000312)\end{array}$ \\
\hline Loans/Secu & $\begin{array}{l}-0.0000181 \\
(0.0000516)\end{array}$ & $\begin{array}{l}0.0000117^{*} \\
(0.00000669)\end{array}$ & $\begin{array}{c}0.00000226 \\
(0.00000514)\end{array}$ & $\begin{array}{l}-0.0000342 \\
(0.0000530)\end{array}$ \\
\hline RWA/TA(t-1) & $\begin{array}{r}0.0149^{* * *} \\
(0.00420)\end{array}$ & $\begin{array}{c}0.0171^{* * *} \\
(0.00230)\end{array}$ & $\begin{array}{c}0.00840^{* * *} \\
(0.00194)\end{array}$ & $\begin{array}{c}0.00318 \\
(0.00354)\end{array}$ \\
\hline$\triangle G D P$ & $\begin{array}{c}0.114^{* * *} \\
(0.0323)\end{array}$ & $\begin{array}{c}0.00782 \\
(0.00840)\end{array}$ & $\begin{array}{l}-0.00110 \\
(0.00737)\end{array}$ & $\begin{array}{r}0.115^{* * *} \\
(0.0330)\end{array}$ \\
\hline Inflation & $\begin{array}{c}0.0891 \\
(0.0672)\end{array}$ & $\begin{array}{c}0.0393^{* * *} \\
(0.0114)\end{array}$ & $\begin{array}{l}-0.0123 \\
(0.0138)\end{array}$ & $\begin{array}{c}0.0744 \\
(0.0594)\end{array}$ \\
\hline Gvt debt (\%GDP) & $\begin{array}{c}-0.0263^{* * *} \\
(0.00387)\end{array}$ & $\begin{array}{r}-0.000575 \\
(0.00214)\end{array}$ & $\begin{array}{l}-0.00790^{* * *} \\
(0.00219)\end{array}$ & $\begin{array}{c}-0.0177^{* * *} \\
(0.00348)\end{array}$ \\
\hline Fiscal balance (\%GDP) & $\begin{array}{c}0.0169 \\
(0.0354)\end{array}$ & $\begin{array}{l}-0.00269 \\
(0.00708)\end{array}$ & $\begin{array}{l}-0.0105^{*} \\
(0.00523)\end{array}$ & $\begin{array}{c}0.0236 \\
(0.0282)\end{array}$ \\
\hline eonia & $\begin{array}{c}-0.190^{* * *} \\
(0.0583)\end{array}$ & $\begin{array}{l}-0.0188 \\
(0.0369)\end{array}$ & $\begin{array}{l}0.00308 \\
(0.0253)\end{array}$ & $\begin{array}{c}-0.161^{* * *} \\
(0.0458)\end{array}$ \\
\hline VIX & $\begin{array}{r}-0.157^{* *} \\
(0.0603)\end{array}$ & $\begin{array}{c}-0.0425^{* *} \\
(0.0193)\end{array}$ & $\begin{array}{l}-0.0146 \\
(0.0274)\end{array}$ & $\begin{array}{r}-0.128^{* *} \\
(0.0594)\end{array}$ \\
\hline VIX2 & $\begin{array}{r}0.00374^{* *} \\
(0.00130)\end{array}$ & $\begin{array}{l}0.00111^{* *} \\
(0.000404)\end{array}$ & $\begin{array}{c}-0.0000548 \\
(0.000603)\end{array}$ & $\begin{array}{c}0.00328^{* *} \\
(0.00130)\end{array}$ \\
\hline Constant & $\begin{array}{c}3.093 \\
(2.346) \\
\end{array}$ & $\begin{array}{c}0.274 \\
(0.912) \\
\end{array}$ & $\begin{array}{l}3.188^{*} \\
(1.781) \\
\end{array}$ & $\begin{array}{c}2.847 \\
(1.744)\end{array}$ \\
\hline $\begin{array}{l}\text { Observations } \\
R^{2}\end{array}$ & 1292 & 1292 & 1292 & 1292 \\
\hline$R^{2}$ & 0.277 & 0.434 & 0.200 & 0.208 \\
\hline $\begin{array}{l}\text { Adjusted } R^{2} \\
\text { r2_btw } \\
\text { rhocoeff }\end{array}$ & $\begin{array}{c}0.270 \\
0.0631 \\
0.691\end{array}$ & $\begin{array}{l}0.428 \\
0.416 \\
0.841\end{array}$ & $\begin{array}{c}0.193 \\
0.0449 \\
0.788\end{array}$ & $\begin{array}{c}0.201 \\
0.0719 \\
0.666\end{array}$ \\
\hline
\end{tabular}

Standard errors in parentheses

Standard deviation clustered over countries

Dependent variables are all scaled by Total Asset(t-1)

No first-order autocorrelation by Wooldgidge test

Hausman test in favour of fixed effects

${ }^{*} p<0.10,{ }^{* *} p<0.05,{ }^{* * *} p<0.01$ 
Table 13: Baseline regression using Core Tier 1 capital

\begin{tabular}{|c|c|c|c|c|}
\hline $\log (\mathrm{TA})$ & $\begin{array}{c}(1) \\
\text { Net Income } \\
0.00703 \\
(0.141)\end{array}$ & $\begin{array}{c}(2) \\
\text { Net Interest Income } \\
0.00172 \\
(0.0423)\end{array}$ & $\begin{array}{c}(3) \\
\text { Net Non-Interest Income } \\
-0.0569 \\
(0.0896)\end{array}$ & $\begin{array}{c}(4) \\
\text { Impairment } \\
-0.0650 \\
(0.114)\end{array}$ \\
\hline CoreT1/RWA(t-1) & $\begin{array}{r}0.0476^{* * *} \\
(0.00731)\end{array}$ & $\begin{array}{r}0.0197^{* * *} \\
(0.00405)\end{array}$ & $\begin{array}{c}0.00547 \\
(0.00595)\end{array}$ & $\begin{array}{r}0.0340^{* * *} \\
(0.00937)\end{array}$ \\
\hline Dep/WS & $\begin{array}{l}-0.000155 \\
(0.000347)\end{array}$ & $\begin{array}{c}0.0000553 \\
(0.0000445)\end{array}$ & $\begin{array}{c}0.0000662 \\
(0.0000531)\end{array}$ & $\begin{array}{l}-0.000200 \\
(0.000313)\end{array}$ \\
\hline Loans/Secu & $\begin{array}{l}-0.0000184 \\
(0.0000546)\end{array}$ & $\begin{array}{c}0.00000954^{* *} \\
(0.00000392)\end{array}$ & $\begin{array}{c}0.00000220 \\
(0.00000433)\end{array}$ & $\begin{array}{c}-0.0000320 \\
(0.0000545)\end{array}$ \\
\hline RWA/TA(t-1) & $\begin{array}{c}0.0144^{* * *} * \\
(0.00476)\end{array}$ & $\begin{array}{c}0.0176^{* * *} \\
(0.00226)\end{array}$ & $\begin{array}{c}0.00863^{* * *} \\
(0.00199)\end{array}$ & $\begin{array}{c}0.00226 \\
(0.00408)\end{array}$ \\
\hline$\triangle G D P$ & $\begin{array}{c}0.114^{* * * *} \\
(0.0332)\end{array}$ & $\begin{array}{c}0.00892 \\
(0.00820)\end{array}$ & $\begin{array}{c}0.00164 \\
(0.00714)\end{array}$ & $\begin{array}{c}0.111^{* * * *} \\
(0.0313)\end{array}$ \\
\hline Inflation & $\begin{array}{c}0.0807 \\
(0.0722)\end{array}$ & $\begin{array}{c}0.0442^{* * *} \\
(0.0129)\end{array}$ & $\begin{array}{l}-0.0143 \\
(0.0133)\end{array}$ & $\begin{array}{c}0.0620 \\
(0.0612)\end{array}$ \\
\hline Gvt debt (\%GDP) & $\begin{array}{c}-0.0285^{* * *} \\
(0.00367)\end{array}$ & $\begin{array}{l}-0.000131 \\
(0.00235)\end{array}$ & $\begin{array}{c}-0.00819^{* * *} \\
(0.00212)\end{array}$ & $\begin{array}{c}-0.0200^{* * *} \\
(0.00331)\end{array}$ \\
\hline Fiscal balance (\%GDP) & $\begin{array}{c}0.0284 \\
(0.0414)\end{array}$ & $\begin{array}{l}-0.00111 \\
(0.00717)\end{array}$ & $\begin{array}{l}-0.00736 \\
(0.00584)\end{array}$ & $\begin{array}{c}0.0331 \\
(0.0331)\end{array}$ \\
\hline eonia & $\begin{array}{c}-0.208^{* * *} \\
(0.0654)\end{array}$ & $\begin{array}{l}-0.0174 \\
(0.0364)\end{array}$ & $\begin{array}{c}-0.00600 \\
(0.0256)\end{array}$ & $\begin{array}{c}-0.172^{* * *} \\
(0.0515)\end{array}$ \\
\hline VIX & $\begin{array}{l}-0.145^{*} \\
(0.0704)\end{array}$ & $\begin{array}{c}-0.0503^{* *} \\
(0.0237)\end{array}$ & $\begin{array}{l}-0.0213 \\
(0.0301)\end{array}$ & $\begin{array}{c}-0.101 \\
(0.0611)\end{array}$ \\
\hline VIX2 & $\begin{array}{c}0.00351^{* *} \\
(0.00146)\end{array}$ & $\begin{array}{l}0.00130^{* *} \\
(0.000500)\end{array}$ & $\begin{array}{c}0.0000990 \\
(0.000650)\end{array}$ & $\begin{array}{c}0.00271^{* *} \\
(0.00126)\end{array}$ \\
\hline Constant & $\begin{array}{c}2.688 \\
(2.955)\end{array}$ & $\begin{array}{c}0.664 \\
(0.800)\end{array}$ & $\begin{array}{c}2.517 \\
(1.719)\end{array}$ & $\begin{array}{c}2.616 \\
(2.335)\end{array}$ \\
\hline Observations & 1145 & 1145 & 1145 & 1145 \\
\hline$R^{2}$ & 0.262 & 0.457 & 0.197 & 0.196 \\
\hline Adjusted $R^{2}$ & 0.254 & 0.451 & 0.188 & 0.188 \\
\hline r2_btw & 0.0727 & 0.411 & 0.0483 & 0.0834 \\
\hline rhocoeff & 0.686 & 0.843 & 0.760 & 0.661 \\
\hline
\end{tabular}

Standard errors in parentheses

Standard deviation clustered over countries

Dependent variables are all scaled by Total Asset(t-1)

No first-order autocorrelation by Wooldgidge test

Hausman test in favour of fixed effects

${ }^{*} p<0.10,{ }^{* *} p<0.05,{ }^{* * *} p<0.01$ 


\section{A.3.3 Robustness check by trimming outliers}

Table 14: Without Baltic countries

\begin{tabular}{|c|c|c|c|c|}
\hline & $\begin{array}{c}(1) \\
\text { Net Income }\end{array}$ & $\begin{array}{c}(2) \\
\text { Net Interest Income }\end{array}$ & $\begin{array}{c}(3) \\
\text { Net Non-Interest Income }\end{array}$ & $\begin{array}{c}(4) \\
\text { Impairment }\end{array}$ \\
\hline $\log (\mathrm{TA})$ & $\begin{array}{l}0.0528 \\
(0.139)\end{array}$ & $\begin{array}{c}0.0325 \\
(0.0475)\end{array}$ & $\begin{array}{l}-0.0597 \\
(0.0921)\end{array}$ & $\begin{array}{r}-0.0327 \\
(0.103)\end{array}$ \\
\hline Equity/TA(t-1) & $\begin{array}{c}0.171^{* * *} \\
(0.0403)\end{array}$ & $\begin{array}{c}0.0687^{* * *} \\
(0.0143)\end{array}$ & $\begin{array}{c}0.0606^{* * *} \\
(0.0190)\end{array}$ & $\begin{array}{c}0.0962^{* * *} \\
(0.0325)\end{array}$ \\
\hline Dep/WS & $\begin{array}{l}-0.000362 \\
(0.000337)\end{array}$ & $\begin{array}{c}0.0000824 \\
(0.0000762)\end{array}$ & $\begin{array}{l}-0.0000101 \\
(0.0000565)\end{array}$ & $\begin{array}{l}-0.000389 \\
(0.000292)\end{array}$ \\
\hline Loans/Secu & $\begin{array}{l}-0.0000136 \\
(0.0000477)\end{array}$ & $\begin{array}{c}0.0000185 \\
(0.0000108)\end{array}$ & $\begin{array}{r}-0.00000351 \\
(0.0000109)\end{array}$ & $\begin{array}{l}-0.0000296 \\
(0.0000489)\end{array}$ \\
\hline RWA/TA $(\mathrm{t}-1)$ & $\begin{array}{c}0.00473 \\
(0.00516)\end{array}$ & $\begin{array}{r}0.0116^{* * *} \\
(0.00223)\end{array}$ & $\begin{array}{c}0.00476^{* *} \\
(0.00168)\end{array}$ & $\begin{array}{l}-0.00203 \\
(0.00426)\end{array}$ \\
\hline$\triangle G D P$ & $\begin{array}{c}0.0716^{* * *} \\
(0.0217)\end{array}$ & $\begin{array}{c}0.00503 \\
(0.00932)\end{array}$ & $\begin{array}{l}-0.00353 \\
(0.00820)\end{array}$ & $\begin{array}{c}0.0747^{* * *} \\
(0.0209)\end{array}$ \\
\hline Inflation & $\begin{array}{l}0.0360 \\
(0.113)\end{array}$ & $\begin{array}{c}0.0207 \\
(0.0129)\end{array}$ & $\begin{array}{l}0.00586 \\
(0.0216)\end{array}$ & $\begin{array}{c}0.0264 \\
(0.0961)\end{array}$ \\
\hline Gvt debt (\%GDP) & $\begin{array}{c}-0.0288^{* * *} \\
(0.00389)\end{array}$ & $\begin{array}{l}-0.00187 \\
(0.00179)\end{array}$ & $\begin{array}{l}-0.00782^{* * *} \\
(0.00185)\end{array}$ & $\begin{array}{c}-0.0193^{* * *} \\
(0.00355)\end{array}$ \\
\hline Fiscal balance (\%GDP) & $\begin{array}{c}0.0249 \\
(0.0357)\end{array}$ & $\begin{array}{r}-0.000312 \\
(0.00670)\end{array}$ & $\begin{array}{r}-0.0129^{* *} \\
(0.00451)\end{array}$ & $\begin{array}{c}0.0297 \\
(0.0291)\end{array}$ \\
\hline eonia & $\begin{array}{r}-0.150^{* *} \\
(0.0621)\end{array}$ & $\begin{array}{l}-0.0184 \\
(0.0337)\end{array}$ & $\begin{array}{c}0.0144 \\
(0.0277)\end{array}$ & $\begin{array}{r}-0.126^{* *} \\
(0.0484)\end{array}$ \\
\hline VIX & $\begin{array}{l}-0.0666 \\
(0.0773)\end{array}$ & $\begin{array}{l}-0.0102 \\
(0.0204)\end{array}$ & $\begin{array}{l}-0.0383 \\
(0.0233)\end{array}$ & $\begin{array}{l}-0.0480 \\
(0.0695)\end{array}$ \\
\hline VIX2 & $\begin{array}{c}0.00161 \\
(0.00157)\end{array}$ & $\begin{array}{c}0.000400 \\
(0.000442)\end{array}$ & $\begin{array}{c}0.000466 \\
(0.000539)\end{array}$ & $\begin{array}{c}0.00136 \\
(0.00144)\end{array}$ \\
\hline Constant & $\begin{array}{l}1.258 \\
(2.740)\end{array}$ & $\begin{array}{r}-0.0487 \\
(0.946) \\
\end{array}$ & $\begin{array}{c}2.574 \\
(1.720) \\
\end{array}$ & $\begin{array}{l}1.627 \\
(2.025) \\
\end{array}$ \\
\hline $\begin{array}{l}\text { Observations } \\
R^{2}\end{array}$ & 1347 & 1347 & 1347 & 1347 \\
\hline$R^{2}$ & 0.303 & 0.481 & 0.254 & 0.200 \\
\hline $\begin{array}{l}\text { Adjusted } R^{2} \\
\text { r2_btw } \\
\text { rhocoeff }\end{array}$ & $\begin{array}{l}0.297 \\
0.121 \\
0.637\end{array}$ & $\begin{array}{l}0.476 \\
0.446 \\
0.843\end{array}$ & $\begin{array}{l}0.247 \\
0.217 \\
0.765\end{array}$ & $\begin{array}{c}0.192 \\
0.0561 \\
0.639\end{array}$ \\
\hline
\end{tabular}

Standard errors in parentheses

Standard deviation clustered over countries

Dependent variables are all scaled by Total Asset(t-1)

No first-order autocorrelation by Wooldgidge test

Hausman test in favour of fixed effects

${ }^{*} p<0.10,{ }^{* *} p<0.05,{ }^{* * *} p<0.01$ 
Table 15: Without top and bottom 1\% observations (per dependent variables)

\begin{tabular}{|c|c|c|c|c|}
\hline $\log (\mathrm{TA})$ & $\begin{array}{c}(1) \\
\text { Net Income } \\
-0.0421 \\
(0.101)\end{array}$ & $\begin{array}{c}(2) \\
\text { Net Interest Income } \\
0.0303 \\
(0.0431)\end{array}$ & $\begin{array}{c}(3) \\
\text { Net Non-Interest Income } \\
-0.103 \\
(0.103)\end{array}$ & $\begin{array}{c}(4) \\
\text { Impairment } \\
-0.0791 \\
(0.0753)\end{array}$ \\
\hline Equity/TA(t-1) & $\begin{array}{c}0.160^{* * *} \\
(0.0300)\end{array}$ & $\begin{array}{c}0.0537^{* * *} \\
(0.0112)\end{array}$ & $\begin{array}{r}0.0448^{* * *} \\
(0.00967)\end{array}$ & $\begin{array}{c}0.0758^{* * *} \\
(0.0173)\end{array}$ \\
\hline Dep/WS & $\begin{array}{l}-0.000187 \\
(0.000215)\end{array}$ & $\begin{array}{c}-0.00000224 \\
(0.0000387)\end{array}$ & $\begin{array}{c}0.0000460 \\
(0.0000464)\end{array}$ & $\begin{array}{c}-0.000149 \\
(0.000180)\end{array}$ \\
\hline Loans/Secu & $\begin{array}{c}0.0000351^{* *} \\
(0.0000131)\end{array}$ & $\begin{array}{c}0.0000176^{*} \\
(0.00000923)\end{array}$ & $\begin{array}{c}-0.000000338 \\
(0.00000837)\end{array}$ & $\begin{array}{c}0.0000102 \\
(0.0000119)\end{array}$ \\
\hline RWA/TA(t-1) & $\begin{array}{l}-0.00219 \\
(0.00332)\end{array}$ & $\begin{array}{c}0.0112^{* * *} \\
(0.00180)\end{array}$ & $\begin{array}{c}0.00400^{* *} \\
(0.00161)\end{array}$ & $\begin{array}{c}-0.00591^{* *} \\
(0.00271)\end{array}$ \\
\hline$\triangle G D P$ & $\begin{array}{c}0.0770^{* * *} \\
(0.0211)\end{array}$ & $\begin{array}{c}0.00715 \\
(0.00731)\end{array}$ & $\begin{array}{l}-0.00474 \\
(0.00686)\end{array}$ & $\begin{array}{c}0.0699^{* * *} \\
(0.0176)\end{array}$ \\
\hline Inflation & $\begin{array}{c}0.131^{* * *} \\
(0.0382)\end{array}$ & $\begin{array}{c}0.0452^{* * *} \\
(0.0143)\end{array}$ & $\begin{array}{l}-0.00555 \\
(0.0134)\end{array}$ & $\begin{array}{c}0.0715 \\
(0.0416)\end{array}$ \\
\hline Gvt debt (\%GDP) & $\begin{array}{c}-0.0212^{* * *} \\
(0.00291)\end{array}$ & $\begin{array}{l}-0.000740 \\
(0.00192)\end{array}$ & $\begin{array}{c}-0.00699^{* * *} \\
(0.00166)\end{array}$ & $\begin{array}{c}-0.0132^{* * *} \\
(0.00337)\end{array}$ \\
\hline Fiscal balance (\%GDP) & $\begin{array}{l}-0.0277^{*} \\
(0.0132)\end{array}$ & $\begin{array}{l}-0.00449 \\
(0.00600)\end{array}$ & $\begin{array}{c}-0.0197^{* * *} \\
(0.00497)\end{array}$ & $\begin{array}{c}-0.00754 \\
(0.0135)\end{array}$ \\
\hline eonia & $\begin{array}{c}-0.0728^{* *} \\
(0.0341)\end{array}$ & $\begin{array}{l}-0.0139 \\
(0.0312)\end{array}$ & $\begin{array}{c}0.0382 \\
(0.0233)\end{array}$ & $\begin{array}{c}-0.0520^{* *} \\
(0.0186)\end{array}$ \\
\hline VIX & $\begin{array}{c}-0.185^{* * *} \\
(0.0381)\end{array}$ & $\begin{array}{c}-0.0559^{* *} \\
(0.0225)\end{array}$ & $\begin{array}{l}-0.0245 \\
(0.0195)\end{array}$ & $\begin{array}{c}-0.116^{* *} \\
(0.0423)\end{array}$ \\
\hline VIX2 & $\begin{array}{r}0.00394^{* * *} \\
(0.000895)\end{array}$ & $\begin{array}{l}0.00137^{* *} \\
(0.000499)\end{array}$ & $\begin{array}{c}0.000120 \\
(0.000442)\end{array}$ & $\begin{array}{l}0.00262^{* *} \\
(0.000956)\end{array}$ \\
\hline Constant & $\begin{array}{l}3.631^{*} \\
(1.845)\end{array}$ & $\begin{array}{c}0.441 \\
(0.748)\end{array}$ & $\begin{array}{l}3.224^{*} \\
(1.845)\end{array}$ & $\begin{array}{l}2.772^{*} \\
(1.345)\end{array}$ \\
\hline Observations & 1353 & 1366 & 1362 & 1356 \\
\hline$R^{2}$ & 0.436 & 0.463 & 0.302 & 0.279 \\
\hline Adjusted $R^{2}$ & 0.431 & 0.458 & 0.295 & 0.273 \\
\hline $\begin{array}{l}\text { r2_btw } \\
\text { rhocoeff }\end{array}$ & $\begin{array}{l}0.150 \\
0.710\end{array}$ & $\begin{array}{l}0.441 \\
0.866\end{array}$ & $\begin{array}{l}0.117 \\
0.781\end{array}$ & $\begin{array}{c}0.0370 \\
0.688\end{array}$ \\
\hline
\end{tabular}

Standard errors in parentheses

Standard deviation clustered over countries

Dependent variables are all scaled by Total Asset(t-1)

No first-order autocorrelation by Wooldgidge test

Hausman test in favour of fixed effects

${ }^{*} p<0.10,{ }^{* *} p<0.05,{ }^{* * *} p<0.01$ 
Table 16: Without top and bottom 1\% observations (per dependent/independent variables)

\begin{tabular}{|c|c|c|c|c|}
\hline & $\begin{array}{c}(1) \\
\text { Net Income }\end{array}$ & $\begin{array}{c}(2) \\
\text { Net Interest Income }\end{array}$ & $\begin{array}{c}(3) \\
\text { Net Non-Interest Income }\end{array}$ & $\begin{array}{c}(4) \\
\text { Impairment }\end{array}$ \\
\hline $\log (\mathrm{TA})$ & $\begin{array}{l}0.0555 \\
(0.129)\end{array}$ & $\begin{array}{c}0.0334 \\
(0.0501)\end{array}$ & $\begin{array}{r}-0.0738 \\
(0.109)\end{array}$ & $\begin{array}{r}-0.0366 \\
(0.108)\end{array}$ \\
\hline Equity/TA(t-1) & $\begin{array}{r}0.201^{* * *} \\
(0.0363)\end{array}$ & $\begin{array}{c}0.0672^{* * *} \\
(0.0108)\end{array}$ & $\begin{array}{c}0.0575^{* * *} \\
(0.0139)\end{array}$ & $\begin{array}{r}0.100^{* * *} \\
(0.0299)\end{array}$ \\
\hline Dep/WS & $\begin{array}{l}-0.000193 \\
(0.000213)\end{array}$ & $\begin{array}{l}-0.0000573 \\
(0.0000640)\end{array}$ & $\begin{array}{l}0.000171^{* *} \\
(0.0000727)\end{array}$ & $\begin{array}{l}-0.000260 \\
(0.000171)\end{array}$ \\
\hline Loans/Secu & $\begin{array}{l}0.0000777 \\
(0.0000522)\end{array}$ & $\begin{array}{c}0.0000487 \\
(0.0000281)\end{array}$ & $\begin{array}{l}-0.0000225 \\
(0.0000276)\end{array}$ & $\begin{array}{l}0.0000306 \\
(0.0000522)\end{array}$ \\
\hline RWA/TA(t-1) & $\begin{array}{l}-0.00316 \\
(0.00368)\end{array}$ & $\begin{array}{c}0.00863^{* * *} \\
(0.00183)\end{array}$ & $\begin{array}{l}0.00320^{*} \\
(0.00176)\end{array}$ & $\begin{array}{l}-0.00543 \\
(0.00390)\end{array}$ \\
\hline$\triangle G D P$ & $\begin{array}{c}0.0712^{* * *} \\
(0.0211)\end{array}$ & $\begin{array}{l}0.00806 \\
(0.00718)\end{array}$ & $\begin{array}{l}-0.00666 \\
(0.00721)\end{array}$ & $\begin{array}{c}0.0595^{* * *} \\
(0.0162)\end{array}$ \\
\hline Inflation & $\begin{array}{c}0.134^{* * *} \\
(0.0402)\end{array}$ & $\begin{array}{c}0.0489^{* * *} \\
(0.0146)\end{array}$ & $\begin{array}{c}-0.00166 \\
(0.0137)\end{array}$ & $\begin{array}{c}0.0731 \\
(0.0422)\end{array}$ \\
\hline Gvt debt (\%GDP) & $\begin{array}{c}-0.0225^{* * *} \\
(0.00260)\end{array}$ & $\begin{array}{l}-0.00179 \\
(0.00214)\end{array}$ & $\begin{array}{l}-0.00755^{* * *} \\
(0.00169)\end{array}$ & $\begin{array}{c}-0.0141^{* * *} \\
(0.00299)\end{array}$ \\
\hline Fiscal balance (\%GDP) & $\begin{array}{c}-0.0317^{* *} \\
(0.0145)\end{array}$ & $\begin{array}{l}-0.00466 \\
(0.00677)\end{array}$ & $\begin{array}{c}-0.0229^{* * *} \\
(0.00488)\end{array}$ & $\begin{array}{r}-0.00631 \\
(0.0136)\end{array}$ \\
\hline eonia & $\begin{array}{c}-0.0690^{* *} \\
(0.0310)\end{array}$ & $\begin{array}{l}-0.0141 \\
(0.0317)\end{array}$ & $\begin{array}{c}0.0401 \\
(0.0249)\end{array}$ & $\begin{array}{l}-0.0493^{* * *} \\
(0.0161)\end{array}$ \\
\hline VIX & $\begin{array}{c}-0.184^{* * *} \\
(0.0390)\end{array}$ & $\begin{array}{l}-0.0606 * * * \\
(0.0203)\end{array}$ & $\begin{array}{l}-0.0277 \\
(0.0196)\end{array}$ & $\begin{array}{r}-0.105^{* *} \\
(0.0430)\end{array}$ \\
\hline VIX2 & $\begin{array}{r}0.00391^{* * *} \\
(0.000913)\end{array}$ & $\begin{array}{r}0.00148^{* * *} \\
(0.000445)\end{array}$ & $\begin{array}{c}0.000187 \\
(0.000449)\end{array}$ & $\begin{array}{l}0.00237^{* *} \\
(0.000982)\end{array}$ \\
\hline Constant & $\begin{array}{c}1.733 \\
(2.462) \\
\end{array}$ & $\begin{array}{c}0.544 \\
(0.925) \\
\end{array}$ & $\begin{array}{c}2.720 \\
(1.965) \\
\end{array}$ & $\begin{array}{c}1.803 \\
(2.015) \\
\end{array}$ \\
\hline Observations & 1295 & 1302 & 1298 & 1293 \\
\hline$R^{2}$ & 0.419 & 0.403 & 0.278 & 0.272 \\
\hline Adjusted $R^{2}$ & 0.413 & 0.397 & 0.271 & 0.265 \\
\hline r2_btw & 0.127 & 0.385 & 0.116 & 0.0268 \\
\hline rhocoeff & 0.726 & 0.875 & 0.784 & 0.708 \\
\hline
\end{tabular}

Standard errors in parentheses

Standard deviation clustered over countries

Dependent variables are all scaled by Total Asset(t-1)

No first-order autocorrelation by Wooldgidge test

Hausman test in favour of fixed effects

${ }_{*}^{*} p<0.10,{ }^{* *} p<0.05,{ }^{* * *} p<0.01$ 
Table 17: Without top and bottom 5\% observations (per dependent variables)

\begin{tabular}{|c|c|c|c|c|}
\hline $\log (\mathrm{TA})$ & $\begin{array}{c}(1) \\
\text { Net Income } \\
-0.0838 \\
(0.0562)\end{array}$ & $\begin{array}{c}(2) \\
\text { Net Interest Income } \\
0.0272 \\
(0.0448)\end{array}$ & $\begin{array}{c}(3) \\
\text { Net Non-Interest Income } \\
-0.0369 \\
(0.0835)\end{array}$ & $\begin{array}{c}(4) \\
\text { Impairment } \\
-0.0943^{* * *} \\
(0.0317)\end{array}$ \\
\hline Equity/TA(t-1) & $\begin{array}{c}0.0845^{* * *} \\
(0.0166)\end{array}$ & $\begin{array}{c}0.0504^{* * *} \\
(0.00951)\end{array}$ & $\begin{array}{c}0.0285^{* * *} \\
(0.00724)\end{array}$ & $\begin{array}{l}0.0243^{*} \\
(0.0117)\end{array}$ \\
\hline Dep/WS & $\begin{array}{c}-0.0000608 \\
(0.000126)\end{array}$ & $\begin{array}{c}0.0000140 \\
(0.0000490)\end{array}$ & $\begin{array}{c}0.0000545 \\
(0.0000495)\end{array}$ & $\begin{array}{c}-0.000141 \\
(0.0000941)\end{array}$ \\
\hline Loans/Secu & $\begin{array}{c}0.00000633 \\
(0.00000525)\end{array}$ & $\begin{array}{c}0.0000288^{* * *} \\
(0.00000539)\end{array}$ & $\begin{array}{c}0.00000155 \\
(0.00000793)\end{array}$ & $\begin{array}{c}-0.00000595^{* * *} \\
(0.00000144)\end{array}$ \\
\hline RWA/TA(t-1) & $\begin{array}{c}0.00227 \\
(0.00183)\end{array}$ & $\begin{array}{c}0.00928^{* * *} * \\
(0.00155)\end{array}$ & $\begin{array}{l}0.00300^{*} \\
(0.00145)\end{array}$ & $\begin{array}{l}-0.00161^{*} \\
(0.000834)\end{array}$ \\
\hline$\triangle G D P$ & $\begin{array}{c}0.0308 * * * \\
(0.00826)\end{array}$ & $\begin{array}{c}0.00461 \\
(0.00712)\end{array}$ & $\begin{array}{l}-0.00389 \\
(0.00665)\end{array}$ & $\begin{array}{c}0.0326^{* * *} \\
(0.00605)\end{array}$ \\
\hline Inflation & $\begin{array}{c}0.0269 \\
(0.0243)\end{array}$ & $\begin{array}{c}0.0314^{* *} \\
(0.0111)\end{array}$ & $\begin{array}{l}-0.0132 \\
(0.0104)\end{array}$ & $\begin{array}{l}0.00436 \\
(0.0143)\end{array}$ \\
\hline Gvt debt (\%GDP) & $\begin{array}{c}-0.0148^{* * *} \\
(0.00285)\end{array}$ & $\begin{array}{l}-0.00165 \\
(0.00166)\end{array}$ & $\begin{array}{c}-0.00688^{* * *} \\
(0.00154)\end{array}$ & $\begin{array}{c}-0.00931^{* * *} \\
(0.00146)\end{array}$ \\
\hline Fiscal balance (\%GDP) & $\begin{array}{r}-0.0258^{* *} \\
(0.00994)\end{array}$ & $\begin{array}{l}-0.00146 \\
(0.00514)\end{array}$ & $\begin{array}{c}-0.0148^{* * *} \\
(0.00486)\end{array}$ & $\begin{array}{l}-0.00151 \\
(0.00580)\end{array}$ \\
\hline eonia & $\begin{array}{l}-0.0187 \\
(0.0254)\end{array}$ & $\begin{array}{l}-0.0201 \\
(0.0271)\end{array}$ & $\begin{array}{c}0.0222 \\
(0.0228)\end{array}$ & $\begin{array}{c}-0.0209^{*} \\
(0.0115)\end{array}$ \\
\hline VIX & $\begin{array}{c}-0.0803^{* *} \\
(0.0315)\end{array}$ & $\begin{array}{c}-0.0397^{* *} \\
(0.0181)\end{array}$ & $\begin{array}{l}-0.0186 \\
(0.0172)\end{array}$ & $\begin{array}{c}-0.0398^{*} \\
(0.0210)\end{array}$ \\
\hline VIX2 & $\begin{array}{c}0.00143^{*} \\
(0.000683)\end{array}$ & $\begin{array}{l}0.00101^{* *} \\
(0.000407)\end{array}$ & $\begin{array}{l}0.0000636 \\
(0.000401)\end{array}$ & $\begin{array}{c}0.000716 \\
(0.000479)\end{array}$ \\
\hline Constant & $\begin{array}{c}3.372^{* * *} \\
(1.007)\end{array}$ & $\begin{array}{c}0.475 \\
(0.807)\end{array}$ & $\begin{array}{c}2.092 \\
(1.527)\end{array}$ & $\begin{array}{c}2.409^{* * *} \\
(0.570)\end{array}$ \\
\hline Observations & 1218 & 1304 & 1248 & 1239 \\
\hline$R^{2}$ & 0.394 & 0.389 & 0.237 & 0.341 \\
\hline Adjusted $R^{2}$ & 0.388 & 0.383 & 0.229 & 0.334 \\
\hline r2_btw & 0.249 & 0.417 & 0.0921 & 0.00434 \\
\hline rhocoeff & 0.705 & 0.852 & 0.763 & 0.774 \\
\hline
\end{tabular}

Standard errors in parentheses

Standard deviation clustered over countries

Dependent variables are all scaled by Total Asset(t-1)

No first-order autocorrelation by Wooldgidge test

Hausman test in favour of fixed effects

${ }^{*} p<0.10,{ }^{* *} p<0.05,{ }^{* * *} p<0.01$ 


\section{A.3.4 Robustness check with interacted terms}

Table 18: Interacted macroeconomic variables: GDP growth

\begin{tabular}{|c|c|c|c|c|}
\hline $\log (\mathrm{TA})$ & $\begin{array}{c}(1) \\
\text { Net Income } \\
0.103 \\
(0.149)\end{array}$ & $\begin{array}{c}(2) \\
\text { Net Interest Income } \\
0.0552 \\
(0.0490)\end{array}$ & $\begin{array}{c}(3) \\
\text { Net Non-Interest Income } \\
-0.0673 \\
(0.0904)\end{array}$ & $\begin{array}{c}(4) \\
\text { Impairment } \\
-0.000581 \\
(0.112)\end{array}$ \\
\hline Equity/TA(t-1) & $\begin{array}{c}0.180^{* * *} \\
(0.0434)\end{array}$ & $\begin{array}{c}0.0628^{* * *} \\
(0.0128)\end{array}$ & $\begin{array}{c}0.0604^{* * *} \\
(0.0165)\end{array}$ & $\begin{array}{c}0.108^{* * *} \\
(0.0364)\end{array}$ \\
\hline Dep/WS & $\begin{array}{l}-0.000223 \\
(0.000283)\end{array}$ & $\begin{array}{c}0.0000277 \\
(0.0000562)\end{array}$ & $\begin{array}{c}0.0000129 \\
(0.0000499)\end{array}$ & $\begin{array}{l}-0.000227 \\
(0.000261)\end{array}$ \\
\hline Loans/Secu & $\begin{array}{c}-0.00000428 \\
(0.0000400)\end{array}$ & $\begin{array}{c}0.0000180^{*} \\
(0.00000857)\end{array}$ & $\begin{array}{c}-0.000000542 \\
(0.00000893)\end{array}$ & $\begin{array}{c}-0.0000212 \\
(0.0000407)\end{array}$ \\
\hline RWA/TA(t-1) & $\begin{array}{c}0.00215 \\
(0.00539)\end{array}$ & $\begin{array}{r}0.0125 * * * \\
(0.00238)\end{array}$ & $\begin{array}{c}0.00467^{* *} \\
(0.00187)\end{array}$ & $\begin{array}{l}-0.00495 \\
(0.00469)\end{array}$ \\
\hline$\triangle G D P$ & $\begin{array}{c}0.0267 \\
(0.0315)\end{array}$ & $\begin{array}{l}-0.00354 \\
(0.00898)\end{array}$ & $\begin{array}{l}-0.0117 \\
(0.0163)\end{array}$ & $\begin{array}{c}0.0409 \\
(0.0367)\end{array}$ \\
\hline$\Delta G D P^{*} \mathrm{RWA} / \mathrm{TA}(\mathrm{t}-1)$ & $\begin{array}{r}0.00136^{* * *} \\
(0.000451)\end{array}$ & $\begin{array}{c}0.000175 \\
(0.000103)\end{array}$ & $\begin{array}{c}0.0000636 \\
(0.000335)\end{array}$ & $\begin{array}{c}0.00120^{*} \\
(0.000659)\end{array}$ \\
\hline Inflation & $\begin{array}{c}0.0652 \\
(0.0769)\end{array}$ & $\begin{array}{c}0.0428^{* * *} \\
(0.0140)\end{array}$ & $\begin{array}{c}-0.00327 \\
(0.0179)\end{array}$ & $\begin{array}{c}0.0415 \\
(0.0671)\end{array}$ \\
\hline Gvt debt (\%GDP) & $\begin{array}{c}-0.0256^{* * *} \\
(0.00327)\end{array}$ & $\begin{array}{c}-0.000800 \\
(0.00191)\end{array}$ & $\begin{array}{c}-0.00815^{* * *} \\
(0.00184)\end{array}$ & $\begin{array}{c}-0.0167^{* * *} \\
(0.00312)\end{array}$ \\
\hline Fiscal balance (\%GDP) & $\begin{array}{c}0.0197 \\
(0.0318)\end{array}$ & $\begin{array}{l}-0.00370 \\
(0.00618)\end{array}$ & $\begin{array}{c}-0.0124^{* *} \\
(0.00504)\end{array}$ & $\begin{array}{c}0.0268 \\
(0.0255)\end{array}$ \\
\hline eonia & $\begin{array}{c}-0.159^{* *} \\
(0.0586)\end{array}$ & $\begin{array}{l}-0.0179 \\
(0.0318)\end{array}$ & $\begin{array}{c}0.0191 \\
(0.0264)\end{array}$ & $\begin{array}{c}-0.138^{* *} \\
(0.0489)\end{array}$ \\
\hline VIX & $\begin{array}{l}-0.101^{*} \\
(0.0495)\end{array}$ & $\begin{array}{l}-0.0395 \\
(0.0229)\end{array}$ & $\begin{array}{l}-0.0220 \\
(0.0241)\end{array}$ & $\begin{array}{l}-0.0674 \\
(0.0490)\end{array}$ \\
\hline VIX2 & $\begin{array}{r}0.00251^{* *} \\
(0.00103)\end{array}$ & $\begin{array}{l}0.00104^{* *} \\
(0.000494)\end{array}$ & $\begin{array}{l}0.0000937 \\
(0.000548)\end{array}$ & $\begin{array}{l}0.00195^{*} \\
(0.00104)\end{array}$ \\
\hline Constant & $\begin{array}{c}0.283 \\
(2.677)\end{array}$ & $\begin{array}{l}-0.289 \\
(0.973)\end{array}$ & $\begin{array}{c}2.569 \\
(1.661)\end{array}$ & $\begin{array}{c}0.903 \\
(1.976)\end{array}$ \\
\hline Observations & 1388 & 1388 & 1388 & 1388 \\
\hline$R^{2}$ & 0.330 & 0.486 & 0.256 & 0.236 \\
\hline Adjusted $R^{2}$ & 0.324 & 0.482 & 0.249 & 0.229 \\
\hline Pvalue_macro & 0.00237 & 0.231 & 0.409 & 0.00501 \\
\hline Pvalue_RWA & 0.0167 & 0.0000892 & 0.0214 & 0.177 \\
\hline
\end{tabular}

Standard errors in parentheses

Standard deviation clustered over countries

Dependent variables are all scaled by Total Asset(t-1)

No first-order autocorrelation by Wooldgidge test

Hausman test in favour of fixed effects

${ }^{*} p<0.10,{ }^{* *} p<0.05,{ }^{* * *} p<0.01$ 
Table 19: Interacted macroeconomic variables: public debt ratio

\begin{tabular}{|c|c|c|c|c|}
\hline & $\begin{array}{l}(1) \\
\text { Net Income }\end{array}$ & $\begin{array}{c}(2) \\
\text { Net Interest Income }\end{array}$ & $\begin{array}{c}(3) \\
\text { Net Non-Interest Income }\end{array}$ & $\begin{array}{c}(4) \\
\text { Impairment }\end{array}$ \\
\hline $\log (\mathrm{TA})$ & $\begin{array}{c}0.123 \\
(0.137)\end{array}$ & $\begin{array}{c}0.0623 \\
(0.0522)\end{array}$ & $\begin{array}{l}-0.0655 \\
(0.0915)\end{array}$ & $\begin{array}{c}0.00510 \\
(0.108)\end{array}$ \\
\hline Equity/TA(t-1) & $\begin{array}{c}0.187^{* * *} \\
(0.0375)\end{array}$ & $\begin{array}{c}0.0654^{* * *} \\
(0.0135)\end{array}$ & $\begin{array}{c}0.0611^{* * *} \\
(0.0183)\end{array}$ & $\begin{array}{c}0.110^{* * *} \\
(0.0309)\end{array}$ \\
\hline Dep/WS & $\begin{array}{l}-0.000204 \\
(0.000301)\end{array}$ & $\begin{array}{c}0.0000335 \\
(0.0000552)\end{array}$ & $\begin{array}{c}0.0000145 \\
(0.0000488)\end{array}$ & $\begin{array}{l}-0.000218 \\
(0.000274)\end{array}$ \\
\hline Loans/Secu & $\begin{array}{r}-0.00000488 \\
(0.0000401)\end{array}$ & $\begin{array}{l}0.0000179^{* *} \\
(0.00000756)\end{array}$ & $\begin{array}{r}-0.000000561 \\
(0.00000916)\end{array}$ & $\begin{array}{l}-0.0000219 \\
(0.0000410)\end{array}$ \\
\hline $\mathrm{RWA} / \mathrm{TA}(\mathrm{t}-1)$ & $\begin{array}{l}0.0260^{*} \\
(0.0124)\end{array}$ & $\begin{array}{l}0.0185^{* * *} \\
(0.00307)\end{array}$ & $\begin{array}{c}0.00638 \\
(0.00415)\end{array}$ & $\begin{array}{l}0.00843 \\
(0.0121)\end{array}$ \\
\hline$\triangle G D P$ & $\begin{array}{c}0.0923^{* * *} \\
(0.0292)\end{array}$ & $\begin{array}{c}0.00310 \\
(0.00755)\end{array}$ & $\begin{array}{l}-0.00896 \\
(0.00838)\end{array}$ & $\begin{array}{r}0.104^{* * *} \\
(0.0316)\end{array}$ \\
\hline Inflation & $\begin{array}{c}0.0558 \\
(0.0792)\end{array}$ & $\begin{array}{c}0.0379^{* * *} \\
(0.0124)\end{array}$ & $\begin{array}{r}-0.00446 \\
(0.0145)\end{array}$ & $\begin{array}{c}0.0429 \\
(0.0689)\end{array}$ \\
\hline Gvt debt (\%GDP) & $\begin{array}{l}-0.0109 \\
(0.00724)\end{array}$ & $\begin{array}{c}0.00310 \\
(0.00283)\end{array}$ & $\begin{array}{r}-0.00706^{*} \\
(0.00393)\end{array}$ & $\begin{array}{l}-0.00891 \\
(0.00704)\end{array}$ \\
\hline Gvt.Debt*RWA/TA(t-1) & $\begin{array}{c}-0.000307^{* *} \\
(0.000135)\end{array}$ & $\begin{array}{c}-0.0000815^{* *} \\
(0.0000306)\end{array}$ & $\begin{array}{l}-0.0000228 \\
(0.0000644)\end{array}$ & $\begin{array}{l}-0.000162 \\
(0.000123)\end{array}$ \\
\hline Fiscal balance (\%GDP) & $\begin{array}{c}0.0139 \\
(0.0281)\end{array}$ & $\begin{array}{l}-0.00525 \\
(0.00653)\end{array}$ & $\begin{array}{c}-0.0128^{* * *} \\
(0.00434)\end{array}$ & $\begin{array}{c}0.0239 \\
(0.0233)\end{array}$ \\
\hline eonia & $\begin{array}{c}-0.143^{* * *} \\
(0.0476)\end{array}$ & $\begin{array}{l}-0.0123 \\
(0.0310)\end{array}$ & $\begin{array}{c}0.0205 \\
(0.0264)\end{array}$ & $\begin{array}{c}-0.134^{* * *} \\
(0.0419)\end{array}$ \\
\hline VIX & $\begin{array}{l}-0.0841 \\
(0.0633)\end{array}$ & $\begin{array}{l}-0.0299 \\
(0.0217)\end{array}$ & $\begin{array}{l}-0.0197 \\
(0.0220)\end{array}$ & $\begin{array}{l}-0.0723 \\
(0.0627)\end{array}$ \\
\hline VIX2 & $\begin{array}{c}0.00211 \\
(0.00132)\end{array}$ & $\begin{array}{l}0.000821^{*} \\
(0.000468)\end{array}$ & $\begin{array}{c}0.0000410 \\
(0.000489)\end{array}$ & $\begin{array}{c}0.00204 \\
(0.00135)\end{array}$ \\
\hline Constant & $\begin{array}{l}-1.449 \\
(2.841)\end{array}$ & $\begin{array}{l}-0.822 \\
(1.074)\end{array}$ & $\begin{array}{c}2.426 \\
(1.736)\end{array}$ & $\begin{array}{c}0.183 \\
(2.238)\end{array}$ \\
\hline Observations & 1388 & 1388 & 1388 & 1388 \\
\hline$R^{2}$ & 0.337 & 0.494 & 0.257 & 0.234 \\
\hline Adjusted $R^{2}$ & 0.330 & 0.489 & 0.250 & 0.226 \\
\hline Pvalue_macro & 0.000000450 & 0.0313 & 0.000856 & 0.0000591 \\
\hline Pvalue_RWA & 0.102 & 0.0000255 & 0.0165 & 0.0934 \\
\hline
\end{tabular}

Standard errors in parentheses

Standard deviation clustered over countries

Dependent variables are all scaled by Total Asset(t-1)

No first-order autocorrelation by Wooldgidge test

Hausman test in favour of fixed effects

${ }^{*} p<0.10,{ }^{* *} p<0.05,{ }^{* * *} p<0.01$ 


\section{A.3.5 Robustness check with crisis dummies}

Table 20: Alternative decomposition of profits with crisis dummies

\begin{tabular}{|c|c|c|c|c|}
\hline & $\begin{array}{c}\text { (1) } \\
\text { Net Income }\end{array}$ & $\begin{array}{c}(2) \\
\text { Recurring Income }\end{array}$ & $\begin{array}{c}(3) \\
\text { Non Recurring Income }\end{array}$ & $\begin{array}{c}(4) \\
\text { Impairment }\end{array}$ \\
\hline $\log (\mathrm{TA})$ & $\begin{array}{l}0.111 \\
(0.163)\end{array}$ & $\begin{array}{l}-0.0261 \\
(0.0860)\end{array}$ & $\begin{array}{c}0.0926 \\
(0.0607)\end{array}$ & $\begin{array}{l}-0.00210 \\
(0.120)\end{array}$ \\
\hline Equity/TA(t-1) & $\begin{array}{c}0.176^{* * *} \\
(0.0411)\end{array}$ & $\begin{array}{l}0.0929^{* * *} \\
(0.0165)\end{array}$ & $\begin{array}{c}0.00833 \\
(0.00619)\end{array}$ & $\begin{array}{c}0.104^{* * *} \\
(0.0341)\end{array}$ \\
\hline Dep/WS & $\begin{array}{l}-0.000216 \\
(0.000279)\end{array}$ & $\begin{array}{c}0.0000129 \\
(0.0000583)\end{array}$ & $\begin{array}{c}0.0000561 \\
(0.0000665)\end{array}$ & $\begin{array}{l}-0.000228 \\
(0.000261)\end{array}$ \\
\hline Loans/Secu & $\begin{array}{r}-0.00000637 \\
(0.0000405)\end{array}$ & $\begin{array}{c}0.0000226^{* * *} \\
(0.00000672)\end{array}$ & $\begin{array}{l}-0.00000463 \\
(0.00000430)\end{array}$ & $\begin{array}{l}-0.0000228 \\
(0.0000412)\end{array}$ \\
\hline RWA/TA(t-1) & $\begin{array}{c}0.00290 \\
(0.00491)\end{array}$ & $\begin{array}{r}0.0165 * * * \\
(0.00244)\end{array}$ & $\begin{array}{l}0.000735 \\
(0.00148)\end{array}$ & $\begin{array}{l}-0.00355 \\
(0.00424)\end{array}$ \\
\hline$\triangle G D P$ & $\begin{array}{c}0.114^{* * *} \\
(0.0335)\end{array}$ & $\begin{array}{c}0.00432 \\
(0.00943)\end{array}$ & $\begin{array}{l}0.00340 \\
(0.0109)\end{array}$ & $\begin{array}{r}0.118^{* * *} \\
(0.0348)\end{array}$ \\
\hline Inflation & $\begin{array}{c}0.0754 \\
(0.0795)\end{array}$ & $\begin{array}{c}0.0510^{* * *} \\
(0.0109)\end{array}$ & $\begin{array}{l}-0.0116 \\
(0.0120)\end{array}$ & $\begin{array}{c}0.0511 \\
(0.0666)\end{array}$ \\
\hline Gvt debt (\%GDP) & $\begin{array}{c}-0.0218^{* * *} \\
(0.00368)\end{array}$ & $\begin{array}{l}-0.00384 \\
(0.00282)\end{array}$ & $\begin{array}{r}-0.000917 \\
(0.00207)\end{array}$ & $\begin{array}{c}-0.0151^{* * *} \\
(0.00337)\end{array}$ \\
\hline Fiscal balance (\%GDP) & $\begin{array}{c}0.0263 \\
(0.0362)\end{array}$ & $\begin{array}{l}-0.00602 \\
(0.00727)\end{array}$ & $\begin{array}{l}-0.00292 \\
(0.00497)\end{array}$ & $\begin{array}{c}0.0287 \\
(0.0292)\end{array}$ \\
\hline eonia & $\begin{array}{c}-0.237^{* * *} \\
(0.0794)\end{array}$ & $\begin{array}{c}0.0159 \\
(0.0364)\end{array}$ & $\begin{array}{r}-0.107^{* *} \\
(0.0480)\end{array}$ & $\begin{array}{c}-0.189^{* * *} \\
(0.0652)\end{array}$ \\
\hline VIX & $\begin{array}{r}-0.130^{* *} \\
(0.0611)\end{array}$ & $\begin{array}{r}-0.0454^{*} \\
(0.0239)\end{array}$ & $\begin{array}{l}-0.0214 \\
(0.0201)\end{array}$ & $\begin{array}{l}-0.102 \\
(0.0594)\end{array}$ \\
\hline VIX2 & $\begin{array}{c}0.00362^{* *} \\
(0.00129)\end{array}$ & $\begin{array}{c}0.000987 \\
(0.000574)\end{array}$ & $\begin{array}{c}0.000557 \\
(0.000569)\end{array}$ & $\begin{array}{c}0.00304^{* *} \\
(0.00131)\end{array}$ \\
\hline Crisis1 & $\begin{array}{r}-0.496^{*} \\
(0.248)\end{array}$ & $\begin{array}{c}0.159 \\
(0.116)\end{array}$ & $\begin{array}{c}-0.432^{* *} \\
(0.175)\end{array}$ & $\begin{array}{l}-0.329 \\
(0.201)\end{array}$ \\
\hline Crisis2 & $\begin{array}{c}0.0491 \\
(0.0898)\end{array}$ & $\begin{array}{r}-0.00121 \\
(0.0460)\end{array}$ & $\begin{array}{l}0.00111 \\
(0.0602)\end{array}$ & $\begin{array}{c}0.102 \\
(0.0853)\end{array}$ \\
\hline Constant & $\begin{array}{c}0.409 \\
(3.038)\end{array}$ & $\begin{array}{c}1.609 \\
(1.527)\end{array}$ & $\begin{array}{l}-0.870 \\
(1.136)\end{array}$ & $\begin{array}{l}1.236 \\
(2.204)\end{array}$ \\
\hline Observations & 1388 & 1388 & 1388 & 1388 \\
\hline$R^{2}$ & 0.328 & 0.557 & 0.083 & 0.230 \\
\hline Adjusted $R^{2}$ & 0.321 & 0.552 & 0.073 & 0.222 \\
\hline r2_btw & 0.191 & 0.431 & 0.00907 & 0.0787 \\
\hline rhocoeff & 0.605 & 0.890 & 0.282 & 0.619 \\
\hline
\end{tabular}

Standard errors in parentheses

Standard deviation clustered over countries

Dependent variables are all scaled by Total Asset(t-1)

No first-order autocorrelation by Wooldgidge test

Hausman test in favour of fixed effects

${ }^{*} p<0.10,{ }^{* *} p<0.05,{ }^{* * *} p<0.01$ 